\title{
An empirical analysis of limited recourse project finance
}

Citation for published version (APA):

Kleimeier, S., \& Megginson, W. L. (2002). An empirical analysis of limited recourse project finance. METEOR, Maastricht University School of Business and Economics. METEOR Research Memorandum No. 066 https://doi.org/10.26481/umamet.2002066

Document status and date:

Published: 01/01/2002

DOI:

10.26481/umamet.2002066

Document Version:

Publisher's PDF, also known as Version of record

\section{Please check the document version of this publication:}

- A submitted manuscript is the version of the article upon submission and before peer-review. There can be important differences between the submitted version and the official published version of record.

People interested in the research are advised to contact the author for the final version of the publication, or visit the DOI to the publisher's website.

- The final author version and the galley proof are versions of the publication after peer review.

- The final published version features the final layout of the paper including the volume, issue and page numbers.

Link to publication

\footnotetext{
General rights rights.

- You may freely distribute the URL identifying the publication in the public portal. please follow below link for the End User Agreement:

www.umlib.nl/taverne-license

Take down policy

If you believe that this document breaches copyright please contact us at:

repository@maastrichtuniversity.nl

providing details and we will investigate your claim.
}

Copyright and moral rights for the publications made accessible in the public portal are retained by the authors and/or other copyright owners and it is a condition of accessing publications that users recognise and abide by the legal requirements associated with these

- Users may download and print one copy of any publication from the public portal for the purpose of private study or research.

- You may not further distribute the material or use it for any profit-making activity or commercial gain

If the publication is distributed under the terms of Article $25 \mathrm{fa}$ of the Dutch Copyright Act, indicated by the "Taverne" license above, 


\title{
AN EMPIRICAL ANALYSIS OF LIMITED RECOURSE PROJECT FINANCE
}

\author{
Stefanie Kleimeier \\ William L. Megginson* \\ Initial Draft: November 1996 \\ Current Draft: July 2001 \\ Comments Welcome
}

* The authors are from, respectively, Universiteit Maastricht, The Netherlands, and the University of Oklahoma, USA. The authors thank Ben Esty, Chris Cornwell, Jimmy Hilliard, Steve Kaplan, Larry Lang, Carlos Maquieira, John Martin, Ashoka Mody, Annette Poulsen, David Schirm, Joe Sinkey, and Art Snow for helpful comments and suggestions. Additionally, we are grateful to the corporate executives who took the time to discuss project finance lending with us during this research. We also appreciate the comments offered by seminar participants at the 1995 Financial Management Association meeting, the 1996 European Finance Association meeting, the 1996 and 2000 European Financial Management Association meetings , the 1999 Harvard Business School Conference on "Complementary Research Methodologies: The Interplay of Theoretical, Empirical and Field-Based Research in Finance", the Maastricht University, the City University Business School (London), and the World Bank. Finally, we are especially grateful for the financial support of the University of Oklahoma's Michael F. Price College of Business, which allowed us to purchase the Loanware database used in this study.

Please address all correspondence to:

William L. Megginson

Professor \& Rainbolt Chair in Finance

Michael F. Price College of Business

307 West Brooks, 205A Adams Hall

The University of Oklahoma

Norman, OK 73019-4005

Tel: (405) 325-2058

Fax: (405) 325-1957

e-mail: wmegginson@ou.edu 


\title{
AN EMPIRICAL ANALYSIS OF LIMITED RECOURSE PROJECT FINANCE
}

\begin{abstract}
This paper provides the first full-length empirical analysis of project finance, which is defined as "limited or non-recourse financing of a newly to be developed project through the establishment of a vehicle company." We compare the characteristics of a sample of 4,956 project finance loans (worth $\$ 634$ billion) to comparable samples of non-project finance loans, all of which are drawn from a comprehensive sample of 90,784 syndicated loans (worth $\$ 13.2$ trillion) booked on international capital markets since 1980. We find that project finance (PF) loans differ significantly from non-project finance loans in that PF loans have a longer average maturity, are more likely to have third-party guarantees, and are far more likely to be extended to non-US borrowers and to borrowers in riskier countries. PF credits also involve more participating banks, have fewer loan covenants, are more likely to use fixed-rate rather than floating-rate loan pricing, and are more likely to be extended to borrowers in tangible-asset-rich industries such as real estate, and electric utilities. Despite being non-recourse finance, floating-rate PF loans have lower credit spreads (over LIBOR) than do most comparable non-PF loans. Contrary to expectations, we find that PF loans are not larger than non-PF loans, but are in fact significantly smaller than corporate control or capital structure loans (two of the four non-PF loan samples examined). Loan pricing regression analysis reveals that PF and non-PF loans are funded in segmented capital markets, with spreads on PF loans being influenced both by different factors and to different degrees by common factors. PF loan spreads are directly related to borrower country risk, the use of covenants in the loan contract, and project leverage. Spreads are also higher when a borrower is in a tangible-asset-rich industry, and loan spreads and fees are shown to be complements rather than supplements. The presence of a third-party guarantee significantly reduces PF loan spreads, while loan size and maturity generally do not influence PF loan pricing. Though direct comparisons of the leverage ratios of project finance vehicle companies and the operating companies that arrange most syndicated loans are not possible, we do find that projects funded with PF loans are indeed heavily leveraged — with an average loan to project value ratio of 67 percent. Finally, when we apply an organizational choice model to a large sample of loans extended to borrowers in industries, which frequently use project finance, we are able to achieve out-ofsample predictive accuracy of almost 80 percent.
\end{abstract}




\section{AN EMPIRICAL ANALYSIS OF LIMITED RECOURSE PROJECT FINANCE}

\section{Introduction}

During the past two decades, an important new method of financing large-scale, high-risk domestic and international business ventures has emerged. This technology, called project finance, is usually defined as limited or non-recourse financing of a newly to be developed project through the establishment of a vehicle company (separate incorporation). Thus the distinguishing features of project finance (PF) are, first, that creditors share much of the venture's business risk and, second, that funding is obtained strictly for the project itself without an expectation that the corporate or government sponsor will co-insure the project's debt--at least not fully.

Project finance was first used on a large scale to develop the North Sea oil fields during the 1970s, where the scale and risk of the investment required far exceeded the capabilities of any single petroleum company, or even any single consortium of companies. ${ }^{1}$ Following the success of the North Sea developments, PF has been used extensively to develop natural resource, electric power, transportation, and numerous other ventures around the world. PF has been associated with many financial and operating success stories. These include the Teeside Power project in the UK, the Ras Laffan LNG project in Qatar, the Hopewell Partners Guangzhou Highway in southern China, and the Petrozuata heavy oil project in Venezuela (see Esty and Millett (1998)), as well as numerous independent power generation projects in the United States. However, PF is most closely associated in the public mind with three spectacular recent financial failures--the Channel Tunnel (Eurotunnel), the EuroDisney theme park outside of Paris, and the Dabhol power project in India. In spite of these failures, total PF lending worldwide has exceeded $\$ 36$ billion every year since 1989 , and reached a peak of $\$ 85$ billion in

\footnotetext{
${ }^{1}$ If project finance is defined more generally as limited recourse financing of stand-alone projects, Kensinger and Martin (1988) quite rightly point out that this financing technique predates stocks or bonds by several centuries. The "modern" form of PF--using a separately-incorporated vehicle company (governed by British or U.S. commercial law), syndicated loan financing, and sophisticated contractual allocation of project risks and responsibilities - is, however, a much more recent invention.
} 
1997 before dropping back to $\$ 54$ billion during the following year's global economic turmoil.

Given its increasing importance as a funding vehicle, it is not surprising that PF has attracted a great deal of academic interest, though the vast majority of published articles and working papers are theoretical rather than empirical studies. The financial packages themselves offer rich opportunities for testing core financial theories using a sample of large, self-contained financial contracts that must both allocate risk and solve basic agency problems between sponsors and creditors. Several theoretical studies examine the characteristic "separate incorporation" feature of project finance. Shah and Thakor (1987) develop a theory of optimal capital structure based on corporate taxes and informational asymmetries, and then use this theory to explain the choice of $\mathrm{PF}$ as an organizational form. In their model, some project values are maximized with separate incorporation (project financing) — and these will have systematically higher leverage ratios than will conventionally-financed projects-because creditors incur lower screening costs in evaluating separately-incorporated project cash flows.

In contrast to Shah and Thakor, Chemmanur and John (1996) develop a symmetric information model of project finance choice that is driven by considerations of the benefits of corporate control. They assert that the control benefits of a particular project are a function of its operating characteristics, and predict that an entrepreneur will seek to maximize the sum of the present value of control benefits (which cannot be contracted away) and security benefits (which can). They then specify the determinants of the optimal organizational choice as a function of firm size, the entrepreneur's ability in managing the specific project (versus other projects under her control), and the level of control benefits and the rate they decline with increasing levels of debt. Generally, the project with the smaller control benefits per dollar of value will be structured as project finance (separately incorporated), and will be allocated a higher debt ratio. Chemmanur (1997) also develops a theory of project finance, but his model explains separate incorporation primarily as an attempt by firms to protect the credit rating of the parent firm, since financing projects through separate subsidiaries may serve to minimize reputation spill-over effects from an ancillary activity. 
Several other streams of theoretical research address other characteristics of project finance, besides the distinctive separate incorporation feature. Numerous recent theoretical breakthroughs in the analysis of secured debt financing, the maturity structure of debt contracts, the choice between private debt (bank loans) and public debt (bonds and notes), the role of covenants and collateral in debt contracts, the optimal design of securities, and the monitoring role of financial intermediaries have all yielded important insights about the observed structure of project finance loans. While an in-depth analysis of this literature is beyond our scope here, key articles include secured debt financing studies by Berkovitch and Kim (1990) and Habib and Johnson (1999); theoretical and empirical analyses of debt maturity structure by Diamond (1991a, 1993), Barclay and Smith (1995), and Guedes and Opler (1996); analyses of the choice between privately and publicly-placed debt presented in Diamond (1991b), Rajan (1992), Chemmanur and Fulghieri (1994), Houston and James (1996), and Repullo and Suarez (1998); theoretical and empirical studies of covenant and collateral usage by Smith and Warner (1979), Berger and Udell (1990), El-Gazzar and Pastena (1990), and Rajan and Winton (1995); theoretical models of optimal security design presented in Boot and Thakor (1993), Boyd and Smith (1994), and Harris and Raviv (1995); and financial intermediation papers by Diamond (1984, 1989), Allen (1990), Bizer and DeMarzo (1992), Johnson (1997), and Allen and Santomero (1998).

The studies cited above collectively help explain several of the stylized facts about project finance presented in three excellent practitioner-oriented overviews by Kensinger and Martin (1988), Smith and Walter (1990), and Brealey, Cooper, and Habib (1996). These commentators assert that PF will most commonly be used for capital-intensive projects, with relatively transparent cash flows, in riskierthan-average countries, using relatively long-term financing, and employing far more detailed loan covenants than will conventionally-financed projects. Brealey, Cooper, and Habib also stress that one of the key comparative advantages of project finance is that it allows the allocation of specific project risks (i.e., completion and operating risk, revenue and price risk, and the risk of political interference or 
expropriation) to those parties best able to manage them. ${ }^{2}$ To our knowledge, however, no full-scale empirical study of project finance has yet been published--apart from Kleimeier and Megginson (1998, 2000), who compare PF in Asia with that in the West and PF with standard syndicated loans, respectively. Our paper seeks to remedy this gap in the literature.

Specifically, our study has three principal objectives. The first is descriptive. Using a comprehensive sample of over 90,000 syndicated loans (worth over $\$ 13$ trillion) booked on international capital markets since 1980, we compare the financial characteristics and geographic and industrial distributions of 4,956 PF loans with various non-PF loan sub-samples and with the full sample of all syndicated loans. Second, we perform OLS regression analyses of the determinants of loan pricing (spreads) for PF and non-PF loans both to determine if PF and non-PF loans are priced in a single integrated market, and to study how borrower and loan-specific factors influence credit spreads. Finally, we estimate an organizational choice model using probit and logit regression techniques, and then apply this to a hold-out sample of loans to determine whether we can predict the choice between traditional and project finance based on observable loan characteristics. We focus this analysis on those industries where $\mathrm{PF}$ is used most frequently in order to neutralize as much as possible the influence of asset characteristics and the operating environment on the project financing choice.

This paper is organized as follows. Section 2 describes the Loanware database used in this study, and also analyzes the industrial and geographic patterns observed for PF versus non-PF lending. The 25 largest project finance deals arranged since 1980 are also described here. In section 3 the financial characteristics of PF loans are compared to the population of all syndicated loans, as well as to four nonPF loan sub-samples. Univariate tests of significant differences between the PF and non-PF loan samples are also presented here. Section 4 presents our separate loan pricing regression analyses of the PF and

\footnotetext{
${ }^{2}$ Other PF studies include Rendell and Niehuss (1983), John and John (1988), World Bank (1994b), Lang (1998), IFC (1999), and Dailami and Leipziger (2000). Focusing on the application of PF to projects in Asia, Lang presents an in-depth analysis of PF and of its requirements for successful implementation in Asia. He also provides detailed descriptions of several actual projects. Dailami and Leipzier investigate the risk premia paid on 27 private foreign currency loans to infrastructure projects in developing countries, but they do not distinguish in their analysis between full-recourse loans and non-recourse project finance loans. Instead they focus on macroeconomic factors, project
} 
non-PF loan samples, and tests whether these loans are funded and priced in a single integrated market or in segmented markets. More in-depth pricing analyses of the main PF sample, plus several sub-samples created based on data availability, are presented in section 5. Our organizational choice (logit and probit regression) models are discussed and applied in section 6 , and section 7 concludes the study.

\section{The Loanware database}

The principal data source used in this study is the Loanware database provided by Capital DATA, a London-based joint venture company between Euromoney plc and Computasoft Ltd. This database contains detailed historical information on virtually the entire population of syndicated loans and related banking instruments that are booked on national and international capital markets from January 1, 1980 through March 23, 1999. ${ }^{3}$ While the file contains information on both signed and unsigned loans, we examine only loans that are actually agreed-to by the contracting parties (signed loans), though we do include the roughly one-eighth of all loans that are subsequently canceled. We also require that the loan size (in \$US millions) be available. After applying these two screens, we are able to examine a total of 90,784 loans (worth $\$ 13.2$ trillion), of which 4,956 loans (worth $\$ 634.4$ billion) have a loan purpose code of Project Finance. We verify with Capital DATA that this screen refers to loans made to a vehicle company, so we refer to this as our "full project finance loan sample," while we call the larger dataset our "all syndicated loan sample."

\subsection{The industrial and geographic distribution of project finance loans}

The full project finance and all syndicated loan samples are described in Tables 1 and 2. Table 1 presents the industrial distribution of the full sample of all loans and the project finance sample, while Table 2 presents the geographic distribution of both loan samples. Both tables reveal striking differences between project finance lending and more traditional syndicated lending, and these differences largely

size, leverage, and industry as the determinants of the risk premia.

${ }^{3}$ Though the database is updated weekly, we freeze the sample as of this date for the current analysis. We will update the sample throughout the journal review process. 
verify the standard picture that is drawn about project finance. Table 1 shows that PF loans are highly concentrated in five key industries, whereas the general population of syndicated loans reveals a far less concentrated industrial pattern. No less than 60.2 percent of all project lending (by value) and 46.3 percent of all PF loans are made to borrowers in the communications, mining and natural resources, oil and gas, electricity and energy utility, and transportation (excluding airlines and shipping) industries. These industries account for only 21.8 percent of all syndicated lending (value) and a mere 17.1 percent of all syndicated loans. This finding is consistent with the received wisdom that project finance is used primarily to fund tangible-asset-rich and capital intensive projects with relatively transparent (often hardcurrency) cash flows. This conclusion is reinforced by the observation that all of the other "overrepresented" industries for PF lending (i.e., construction/heavy engineering, hotels and leisure, petrochemicals) can be described similarly.

\section{$* * * *$ Insert Tables $1 \& 2$ about here $* * * *$}

Table 2 also presents a revealing difference between the countries which attract PF lending and those where other types of syndicated credits are directed. Whereas the vast bulk of general syndicated lending is concentrated in the United States (61.4 percent by value and 56.6 percent of all loans), only 16.8 percent of PF lending and only 14.7 percent of PF loans go to U.S. borrowers. The biggest recipient of PF lending is south-east Asia. This region accounts for 23.8 percent of the total value--and no less than 30.3 percent of the total number--of project finance loans, whereas it accounts for a mere 5.2 percent of the value (and 10.8 percent of the number) of all syndicated lending. Closer analysis reveals that PF lending to south-east Asia peaked in 1996, and has fallen dramatically since then, but this region was the heart and soul of PF lending for almost a decade prior to that date - with Indonesia and China being the two favorite target countries. Intriguingly, U.K. borrowers are more heavily represented in the PF sample than in the full syndicated loan sample (14.5 percent by value versus 9.3 percent), although the rest of western Europe accounts for an almost identical fraction (10.3 versus 10.4 percent) of both types of lending. This preference of project finance lenders for British borrowers is not merely an artifact of the 
disproportionately large Eurotunnel loans (discussed below). It also reflects the emphasis placed by the Conservative Thatcher and Major governments (and now the Labor government of Tony Blair) on the private rather than public financing of large infrastructure projects - many of which have proven to be remarkably successful, both financially and operationally. As a whole, these geographic lending patterns are consistent with the widely held belief that project finance is a particularly appropriate method of funding projects in relatively risky (non-OECD) countries.

\subsection{Characteristics of the largest project finance deals}

Table 3 presents key details regarding the 25 largest project finance loan packages arranged since 1980. These are listed by the total value of the project, since some packages have as many as four separate loan tranches--which are listed separately, with their corresponding financial information, within each project's cell in the table. There are a total of 46 loans associated with these 25 project finance packages, or an average of 1.84 loans per project finance deal. The infamous Eurotunnel project has the distinction of being both the largest and second largest project financing in history, though the $\$ 13.2$ billion loan in June 1990 was only a refinancing of the original $\$ 7.9$ billion loan package arranged in August 1987. These 25 deals reveal many of the key features commonly associated with project finance. In all cases, borrowing is done through a newly created vehicle company set up to finance, build, and operate the project. Additionally, project sponsors are usually well known international operating companies, state-owned enterprises, and/or governmental bodies that are joined together through ownership of the vehicle company and by the supplemental project financing contractual agreements. Further, the loans themselves tend to be relatively long-term credits, and are priced at a fixed spread above a benchmark interest rate, typically the London Inter-Bank Offered Rate (LIBOR). Another distinctive feature of these loans is that they frequently include a loan tranche that is fully or partially guaranteed by a creditworthy third party, usually a developed country's export credit agency (though the World Bank is a frequent guarantor of smaller PF loans in this database).

\footnotetext{
$* * * *$ Insert Table 3 about here $* * * *$
} 
Perhaps the most telling difference between the large PF loans detailed in Table 3 and more traditional syndicated credits is the use to which they are put. Whereas (as we will discuss in detail below) most non-PF loans are arranged to finance acquisitions or LBOs, for refinancing existing financing facilities, or for general corporate purposes, all of the large PF loan packages are associated with specific construction projects--though three are refinancing of earlier credits. No less than seven of these involve telecommunications projects, with five being arranged to finance the rollout of mobile phone networks. An additional five packages are arranged to build rail, tunnel, or subway projects, while four are dedicated to constructing electrical utility or cogeneration facilities. Four of the remaining loan packages are allocated to petrochemical projects, and two are arranged to finance the construction of cross-border natural gas pipelines. Once again, the received wisdom regarding project finance rings true: at least the largest such loan packages are complex, international financial deals involving a vehicle company owned by multiple sponsors, and are arranged to fund development of large, tangible-asset-based projects. The loans are often guaranteed by third parties (though the entire package rarely is — only individual loan tranches), and the projects are often located in relatively risky countries. We now turn to a direct comparison of PF loans with various subsamples of non-PF loans, categorized by their intended use.

\section{Financial characteristics of project finance versus non-project finance loans}

Panel A of Table 4 presents basic financial characteristics for the full sample of all syndicated loans, the full sample of PF loans, and four additional, non-overlapping samples of syndicated loans classified by loan purpose. The category of corporate control loans includes those credits with loan purposes codes indicating that they are being arranged to fund acquisitions, leveraged buyouts, or employee stock option plans. Capital structure loans are those booked in order to repay maturing lines of credit or for recapitalizations, share repurchases, debtor in possession financing, standby commercial paper support, or other (unspecified) refinancing. Fixed asset based loans have loan purpose codes indicating they are intended for mortgage lending or to fund purchases of aircraft, property, or shipping. 
The general corporate purpose loans category includes loans with that as their stated purpose, as well as credits with an empty loan purpose code. Loans with other purposes are not grouped here into a separate category, though they are included in the full sample of syndicated loans. ${ }^{4}$ This categorization strategy, though admittedly ad hoc, effectively groups together loans having similar corporate purposes and provides a manageable set of loan type samples that can be directly compared to each other. ${ }^{5}$

\section{$* * * *$ Insert Table 4 about here $* * * *$}

Panel A of Table 4 reveals striking — and highly significant--differences both between PF and non-PF loans, as well as between the various categories of traditional loans. One of the most dramatic findings is how much larger are corporate control and capital structure loans than other loan types. These credits have mean (median) values of \$212 million (\$59 million) and \$209 million (\$65 million), respectively, compared with $\$ 146$ million ( $\$ 50$ million) for the full population of all syndicated loans and a "mere" \$88 million ( $\$ 50$ million) for fixed asset based loans. The converse of this result is the surprising finding that project finance loans are, on average, \$18 million smaller than the general population of syndicated loans ( $\$ 128$ million versus $\$ 146$ million), though the median PF loan size is $\$ 2$ million greater ( $\$ 52$ million versus $\$ 50$ million). These relative size differences remain even when size is expressed as the total value of all loan tranches rather than as individual loans. While the size difference between PF and corporate control loans can be explained away by stressing that the latter involves purchasing an entire company, the fact remains that PF loans are not abnormally large financing vehicles - but rather fall well within the mainstream of syndicated lending.

According to all four of the remaining variables in Table 4's Panel A, however, PF loans are substantially different financial instruments. The average maturity of PF loans, 8.6 years, is almost twice

\footnotetext{
${ }^{4}$ We also grouped these credits into an "Other loans" sample, and subjected these to the same basic tests as the five principal categories. This sample was very similar to our "General corporate purpose loans" sample in general characteristics, so we do not report these tests here in the interests of space. These results are available upon request. ${ }^{5}$ We should point out that hitting on the precisely "appropriate" method of categorizing non-PF loans is not critical to our main empirical objective in this and the next section, which is to test whether PF and non-PF loans are significantly different financial instruments. Our results are very robust to most non-PF loan classification schemes, though the observed similarity between PF and fixed asset-based loans does make the selection criteria for that category important. Fortunately, these are the easiest non-PF loans to identify.
} 
that of the full population of syndicated loans, and is comparable only to the 8.1 year average of fixed asset based loans. Additionally, compared to the overall sample of syndicated loans and most of the subsamples, PF loans are more than twice as likely to be fixed rate credits (13.9 percent versus 5.9 percent). Further, those PF loans that are priced as a floating rate use LIBOR as a pricing base far less frequently (38.8 percent) than the full syndicated loan sample (69.5 percent). ${ }^{6}$ Perhaps the single most remarkable difference between PF and all non-PF loans is how infrequently project finance loans are extended to U.S. borrowers. Whereas American corporations (and occasionally governmental units) arrange 55.8 percent of all syndicated loans, by value, and account for fully 74.0 percent of capital structure lending, U.S. borrowers account for a mere 13.9 percent of project finance lending. The only other category of loans with a similar non-U.S. flavor are the fixed asset based credits, which we will find share many important characteristics with PF loans.

\subsection{Loan pricing samples}

One of the most important objectives of this study is to determine whether PF loans are more or less expensive for borrowers than are other types of loans. To address this issue, we select from the sample of all syndicated loans those credits which are both priced as floating rate loans and which use LIBOR as a base interest rate. We also screen for complete data on borrower nationality and loan currency denomination. These screens yield a set of "high-information" loan samples with comparable pricing data expressed, in basis points, as spreads above LIBOR. These are presented in Panel B of Table 4, beginning with the full sample of 40,073 high-information syndicated loans. The various loan purpose sub-samples are presented next, beginning with the 1,824 project finance loans priced as a spread over LIBOR. The relatively low "survival rate" of PF loans from the full sample to the high-information subsample (36.8 percent of the original 4,956 loans) is due to their pricing characteristics. As noted earlier, PF loans are more commonly fixed price credits than are other types of loans and fewer of the floating

\footnotetext{
${ }^{6}$ After LIBOR, the next most common bases for pricing project finance loans are the Singapore and Hong Kong Inter-Bank Offered Rates (SIBOR and HIBOR), with 118 and 82 loans, respectively. A surprisingly large number of $1,830 \mathrm{PF}$ loans list a spread, in basis points (thus confirming they are floating rate credits), but do not specify the base against which the loan is priced. Running our main analyses with these classified as LIBOR-based loans yields
} 
rate PF loans are priced versus LIBOR. Nonetheless, a comparison of the variables common to the loan samples in Panels A and B reveals that the high-information PF loans in Panel B are not dissimilar to their counterparts in Panel A in terms of average loan size, maturity, and frequency of U.S. borrowers. The same is true for the other loan type sub-samples, so we will assume that any empirical results derived from the high-information sub-samples are generalizeable to the larger population of all loans.

In addition to the variables discussed earlier, Table 4's Panel B presents several new loan structure variables as well as greater detail about borrowers and the use for which a loan is arranged. Most of these are self-explanatory (i.e., fee levels, number of banks in a syndicate, loans with guarantees), but a few require definition. We define a loan as having currency risk if the denomination of the loan (and its currency of repayment) differs from the currency of the borrower's home country. Thus a Japanese borrower arranging a dollar loan would be subject to currency risk, whereas that same borrower arranging a yen-denominated loan would not be. Country risk rank and country risk score are taken directly from the semi-annual country risk tabulation in Euromoney magazine. A low-risk country will have a very low rank but a very high score. For example, Luxembourg and the United States were ranked 1 and 2 in late 1998 (Switzerland also typically ranks very high), but Luxembourg's score was 98.9 and the U.S.' score was 97.85 . On the other hand, extremely risky countries have high rankings and low scores (in late 1998, North Korea and Afghanistan had rankings of 179 and 180, respectively, and scores of 2.25 and 2.01). While we report both risk rank and risk scores in Panel B, in the interest of space we will subsequently report only empirical results using country risk rank data, since this is the only risk measure reported by Euromoney during the 1980-1982 period. As will be discussed more fully below, rank also has econometric advantages in the loan pricing regressions, since it assigns an increasing value to countries with higher risk — which is also how spreads should be correlated with risk. In all cases, the results using country risk score are qualitatively similar, though the regression intercepts differ substantially.

The variable loans with covenants indicates whether the loan agreement legally imposes any of

qualitatively similar results. 
the standard positive or negative covenants on the borrower. Since this variable suffers from a missing value problem (an empty cell may mean that the loan has no covenants or that the data is unavailable), we report it simply as the fraction of each loan type with covenants included. Finally, the variable loans to collateralizeable asset-rich borrowers is a dummy variable coded as 1 if the borrower is operating in an industry generally believed to be rich in non-specialized, tangible (and thus collateralizeable) assets. Specifically, this means that the loan recipient has a business borrower code of airlines, apartment management, electricity utility, hotels and leisure, property, REIT, or shipping. Both the theoretical and empirical capital structure literature (see especially Bradley, Jarrell, and Kim (1984)) indicates that companies with many such assets should be able to tolerate heavier debt levels than other companies. Panel C of Table 4 provides t-tests comparing the values of each variable in the high-information PF loan sample with the corresponding values in the (high-information) all syndicated loan sample and in the other four loan purpose sub-samples. The numbers in this panel are t-statistics and almost all of the pairwise comparisons indicate statistically significant differences between the PF sample values and the corresponding values for other loan categories.

The relative pricing of PF versus non-PF loans is one of the most important, and surprising, findings detailed in Panel B of Table 4. Average loan spreads are statistically and economically significantly lower for PF loans (130 bp) than they are for corporate control loans (195 bp), capital structure loans (135 bp) and the full sample of all syndicated loans (134 bp). Most observers would have predicted that PF loans have higher spreads than non-PF loans, since loan repayment is not guaranteed by the project's sponsor (limited or non-recourse lending) and because of most projects' higher perceived risk levels.

The observed level of loan fees and the number of participating banks do provide indirect evidence that PF lending may well be considered relatively more risky than other types of lending — or at least more difficult to arrange. The average levels of commitment and participation fees for PF loans (36.9 and $56.3 \mathrm{bp}$, respectively) are significantly higher than the levels for the full sample of syndicated 
loans (30.8 and $36.9 \mathrm{bp}$ ), as well as for every sub-sample except corporate control loans. Additionally, the average number of banks participating in PF loans (14.5 banks) is significantly larger than the average for all loans (10.7 banks) and the average for every other loan sub-sample. These findings suggest that banks must be compensated with relatively high up-front fee payments to entice them to participate in project finance lending, and they are apparently unwilling to take as large a stake in PF loans as they would in other credits. Either that or they wish to increase the number of banks participating in a PF credit of a given size in order to spread risks over a larger number of banks for some other reason, such as to build political support. We will examine loan pricing more fully in the next section, when we employ OLS regression to determine what factors influence loan spreads.

Most of the non-price variables detailed in Panel B clearly suggest that PF loans are often similar to fixed asset based loans (FAB), but are otherwise fundamentally different financial instruments from other loan types. As before, a far lower fraction of both PF and FAB loans are arranged for U.S. borrowers (11.6 and 13.4 percent) than is true for the overall sample of all syndicated loans (56.9 percent), and these loans also have much longer average maturity ( 8.6 and 7.7 years versus 4.8 years). Additionally, PF and FAB loans are much more likely to be subject to currency risk than are other loan types (72.9 and 71.0 percent for PF and FAB loans, respectively, versus 33.1 percent for all syndicated loans). Given the non-U.S. nature of typical PF and FAB borrowers, coupled with the fact that syndicated loans are overwhelmingly dollar-denominated, this high level of currency risk is not surprising. Furthermore, a significantly larger fraction of PF and FAB loans carry third-party guarantees (34.1 and 34.5 percent, respectively) than of the full sample of all syndicated loans (13.3 percent) or any other subsample.

$\mathrm{PF}$ and FAB loans share one other intriguing (and surprising) common feature--they are far less likely to contain loan covenants than are all other loan types. Only 3.4 percent of PF loans, and 7.1 percent of FAB loans, have at least one positive or negative loan covenant versus 30.5 percent of all syndicated credits and 42.4 percent of capital structure loans. We are frankly at a loss to explain why 
FAB loans have so few covenants - unless these are primarily mortgages, specifically tied to individual assets, which give creditors senior enough positions not to require separate loan covenants. We can, however, offer two possible explanations for the absence of covenants for project finance loans-which received wisdom suggests should be loaded with exquisitely detailed contractual provisions. First, since this database details PF loans, rather than the full financial deals themselves, it is likely that the explicit debt covenants for project finance packages are covered by a separate contract (the project financing package), so the PF loans themselves are simply one part of a much larger deal. No such separate contract governs a takeover loan or a debt refinancing credit extended to an operating company, however, so in those cases the covenants are included in the loans themselves. The second hypothesis really has greater implications for general corporate finance than for a project finance study, though the separate incorporation feature of PF is central to its logic. Since loan covenants are designed in part to protect the creditor from asset substitution and other methods of wealth expropriation by the borrower, it follows that these clauses are far less necessary for loans to a special-purpose vehicle company than they are for loans made to a complex, multi-divisional corporation.

For three of the characteristics detailed in Panel B, PF and FAB loans differ significantly from each other-though they remain more similar than in comparison to other loan categories. The first two such features are the country risk measures. PF loan borrowers are, on average, located in far riskier countries than is the case for any other loan category. The average country risk rank for PF borrowers (31.8) is significantly higher than the corresponding value for FAB loans (21.3), and is dramatically higher than the average risk rank for all syndicated loans (12.8). Using late-1998 Euromoney scores, this suggests that the typical syndicated loan is arranged for a borrower in Sweden, a typical FAB loan would go to a borrower in Singapore, while the typical PF credit would be arranged for a company in Bahrain. Average country risk scores for PF, FAB, and all syndicated loan borrowers (74.6, 82.7, and 90.0, respectively) tell a similar story, corresponding as they do to arranging loans for borrowers in Qatar, Cyprus, and Australia. Clearly, project finance loans involve significantly greater political and economic 
risk than any other major category of syndicated credit.

Perhaps one reason PF loans can be made to relatively risky borrowers is because they are much more likely to be arranged for collateralizeable asset-rich projects than is the case for the average syndicated loan. Over one-quarter (27.7 percent) of PF loans are extended for such projects, versus only 14.2 percent of all syndicated loans. On the other hand, the fraction of FAB loans arranged for this type of borrower, 69.5 percent, is the highest of any loan category — which is not surprising since this category was defined to be tangible asset rich.

Before proceeding to a multivariate regression analysis of loan pricing, we should briefly summarize the results of our univariate comparisons between PF loans and other loan types. Project finance loans fall, on average, in the middle range of all syndicated lending in terms of size and loan spread (price). On the other hand, PF loans have much longer average maturity and are more likely to be fixed rather than floating rate credits (and are less likely to be priced relative to LIBOR if they are floating rate). American companies use project finance only sparingly; whereas over half of all syndicated loans are arranged for U.S. borrowers, only one-eighth of PF loans are booked for American vehicle companies. In fact, the average PF loan borrower resides in a much riskier country than is true for syndicated lending in general, and PF lending is significantly more likely to be arranged for a tangible asset rich project. Finally, PF loans share many similarities with fixed asset based credits—such as borrower nationality, average loan size and maturity, frequent use of third-party guarantees, and infrequent use of loan covenants. On the other hand, they also differ in being more expensive than FAB loans and in being extended to relatively riskier, and less tangible-asset rich borrowers.

\section{Loan pricing regression analyses}

In this section, we subject the various high-information loan samples detailed in Table 4, Panel B to OLS regression analysis. Our purposes in doing this are three-fold. First, we wish to determine which of the variables detailed in Table 4 have significant, independent influences on loan spreads once the 
effects of other variables are accounted for. Second, we wish to determine whether the several categories of loans are priced in the same way—whether the coefficient values and number of significant factors is the same between all of the groups. This is equivalent to testing whether these different loan types are priced in segmented or integrated capital markets. Finally, we wish to determine whether PF loans are more or less expensive than other types of loans - again, after accounting for other factors.

The academic literature contains numerous examples of loan pricing studies, using both bank loans and publicly-traded debt. Theoretical pricing models are presented in Merton (1984), Black and Cox (1976), Eaton, Gersovitz, and Stiglitz (1986), Maksimovic (1990), Longstaff and Schwartz (1995), and Duffee (1998). Empirical pricing studies include Smith (1980), Edwards (1984, 1986), Melnik and Plaut (1986), Scott and Smith (1986), Berger and Udell (1990), Boehmer and Megginson (1990), Booth (1992), Petersen and Rajan (1994), Chen, Mazumdar, and Hung (1996), Blackwell and Winters (1997), Chen, Mazumdar, and Yan (2000), and Eichengreen and Mody (2000). ${ }^{7}$ The loan pricing tests we perform are most similar to those presented in Booth (1992), both in the actual model estimated and in the average size of loans under examination. Our sample size is, however, many times larger than in Booth or almost any other study cited above.

We estimate the determinants of loan pricing using the model described in equation 1 . The dependent variable is the loan spread above LIBOR, in basis points, and the independent variables are those presented and discussed in Table 4. We employ standard OLS regression estimation techniques and adjust for heteroskedasticity using the methodology proposed by White (1980). The model estimated is:

$$
\begin{aligned}
\text { Spread }= & \alpha+\beta_{1} \text { Size }+\beta_{2} \text { Maturity }+\beta_{3} \text { Guarantee }+\beta_{4} \text { Currency Risk }+\beta_{5} \text { Country Risk Rank } \\
& +\beta_{6} \text { Collateralizeable Assets } \quad \text { (1) }
\end{aligned}
$$

\footnotetext{
${ }^{7}$ Although Carey, Post, and Sharpe (1998) do not estimate a loan pricing model, per se, this paper is also relevant here because they do examine the influence of borrower risk and information asymmetries on the credit decisions of financial intermediaries. Several other papers provide useful information on the U.S. syndicated loan market (Booth and Chua (1995), Barnish, Miller, and Rushmore (1997), Culp and Neves (1998)), the structures employed for international syndicated lending (Chowdry (1991)), and the importance of third-party guarantees in PF lending (World Bank (1994a,c), Mody and Patro (1995)).
} 
Where:

Size $=$ Loan size, in US\$ millions;

Maturity = Loan maturity, in years;

Guarantee $=$ Dummy variable taking the value of 1 if a loan has a third-party guarantee and 0 otherwise;

Currency Risk $=$ Dummy variable taking the value of 1 if a loan is exposed to currency risk (the currency of the loan repayment cash flows differs from the borrower's home country currency), and 0 otherwise;

Country Risk Rank = Country risk rank, an integer ranking of country risk provided by Euromoney every year, where low risk countries have low ranks (Luxembourg =1 in late-1998) and high risk countries have high ranks (North Korea $=179$ );

Collateralizeable Assets $=$ Dummy variable taking the value of 1 if the borrower is in an industry generally considered to be rich in collateralizeable (tangible, non-specialized) assets, and 0 otherwise.

We employ country risk rank as our measure of country risk, rather than risk score, both because this yields two additional years of data, and because this measure increases with country risk--which lends itself to a more logical interpretation of the coefficient on the risk variable coefficient. For example, if rank's coefficient value is 1.50 , this implies that a loan booked to a borrower in a country with a risk ranking of 40 will on average have a spread 15 basis points higher than a loan to a borrower in a country with a rank of 30 .

We should also explicitly state that this model does not have a variable measuring credit risk in any direct way--such as borrower solvency, liquidity, or leverage ratios — despite the likelihood that such a proxy would prove very useful. There are two reasons for this. First, the Loanware database does not provide a machine readable identification code (i.e., CUSIP or Datastream identification number) for borrowers, so there is no feasible method of matching borrowers to their corresponding accounting or 
stock price data. Second, it is not at all clear that debt or liquidity ratios for PF borrowers would be comparable to similar ratios for borrowers of other syndicated loans. Whereas the borrower of all other types of syndicated credits is usually an operating company, which promises its entire faith and credit to repayment of the loan, the PF borrower is, by definition, a vehicle company without external assets or sources of repayment. Thus the implied corporate backing for a syndicated loan to, say, Enron is fundamentally stronger than the backing for a loan to a vehicle company being sponsored by Enroneven if Enron is the sole project sponsor. Other things equal, this lack of corporate guarantee of loan repayment should make these loans riskier and thus more expensive than other types of loans. The key question we hope to answer is whether the project financing structure is sufficiently good at overcoming agency problems, and/or at reducing contract monitoring and enforcement costs, to overcome this lack of corporate backing. If so, PF loans will not be more expensive than other loan categories-and may even have lower spreads.

Table 5 presents the results of estimating equation 1 using each of the five loan samples discussed in section 3. We must begin by estimating these samples separately—only if we find they are priced in a single integrated market can we estimate the full sample of all syndicated loans in a single regression. The regression intercepts for each loan sample are comfortingly close to the univariate loan price (spread) averages presented in Panel B of Table 4, and also show similar relative patterns (highest for corporate control, lowest for fixed asset-based loans). The intercept for PF loans, 131.4 basis points, is in fact less than two basis points different from the average spread presented in Table 4's Panel B (130 bp). The PF intercept is also the second lowest of any loan sample. This finding, coupled with the univariate test results showing that PF loans have significantly lower spreads than other loan groups, clearly suggests that project finance lending has competitive advantages over other loan forms - at least for funding certain projects.

\section{$* * * *$ Insert Table 5 about here $* * * *$}

The second line of Table 5 details the influence of loan size on spreads, which is insignificant for 
project finance but negative and significant for all other loan samples. The coefficient values for size on non-PF loans ranges from -0.02 to -0.06 , with a weighted average of around -0.05 . This suggests that increasing the size of a non-PF syndicated loan by $\$ 100$ million will reduce the required loan spread by an average of 5 basis points. This negative size/spread relationship could be due to economies of scale in arranging non-PF syndicated credits, or it could be due to better known and more creditworthy borrowers being able to arrange larger loans. Since size is not a significant influence on PF loan prices, we do not attempt a further analysis here. Clearly, however, this finding merits further study.

Loan term is a second variable that behaves differently for project finance than for any other loan type. Whereas spread and maturity are significantly, positively related for all other loan categories, they have a significant negative relationship for PF loans. The coefficient value for term indicates that booking a loan with an original maturity one year longer than the median reduces the average project finance loan spread by 0.89 basis points. A one year increase in maturity would increase spreads for other loan categories--by up to 9.1 basis points for corporate control loans. Since PF loans have an average (and median) maturity that is more than twice that of most other loan types, this result is readily explainable (without a negative spread/term relationship, long tenor loans would be prohibitively expensive), though still surprising.

While finding a consistently significant, negative relationship between spread and guarantee across all loan samples is not surprising, the dispersion in coefficient values definitely is. Whereas the presence of a third-party guarantee reduces the spread on a typical capital structure loan by only 3.7 basis points, a similar guarantee reduces the spread on project finance loans by almost 43 basis points. No other loan category has nearly this sensitivity to third-party guarantees; the next highest value, -19.6 basis points for corporate control, is less than half as large. This result also shows why PF borrowers are so much more willing than are most other borrowers to incur the cost (in time, effort, and cash) required to arrange guarantees. The payoff, in terms of a reduced loan price, is much larger.

In yet another surprise, the currency risk dummy has a significantly negative relationship with 
loan spreads for every loan category. This finding suggests that a mismatch in the currency of the borrower's home country and the currency of loan repayment significantly reduces the rate charged on an average loan--by 42 basis points for PF credits and by up to 99 basis points for general corporate purpose loans. One obvious interpretation of this is that banks offer lower rates to international borrowers who are willing to accept the risk of borrowing in dollars or another hard currency, though it is not clear why this would not be offset by increasing borrower default risk.

An alternative, more intriguing, explanation for the negative spread/currency risk relationship is that it might be the result of a yield premium charged to U.S. borrowers. Various empirical permutations of this database consistently yield the result that American corporate borrowers pay higher rates for loans of a given size, maturity, and purpose than do non-U.S. borrowers. We can offer three possible explanations for this U.S yield premium. First, it could be that more American corporations have access to the syndicated loan market than do companies from other countries-implying that the average credit rating of US borrowers will be lower. Second, it could be that a larger fraction of U.S. than non-U.S. syndicated lending is for takeover financing, which as we've shown is on average larger and carries a higher spread than does any other type of loan. This type of lending may also offer banks higher spreads because of the corporate borrower's need to arrange large credit lines both rapidly and discretely. The third possible explanation is that there are institutional features (inadequate competition, increased litigation risk, greater compliance costs, etc.) of the syndicated loan market in the United States that act to increase loan rates charged to all American corporate borrowers relative to rates charged to non-U.S. borrowers. This finding also merits more in-depth analysis than we can provide here.

The final variable in Table 5, collateralizeable assets, is always significant - though it has a negative relationship with spread for corporate control, general corporate purpose, and capital structure loans, and a positive relationship with spreads for PF and FAB credits. This means that, for most loans, a borrower in a collateralizeable asset-rich industry will be charged a lower interest rate than will borrowers in other industries, but the reverse is true (with roughly equal force) for project finance and FAB lending. 
The negative coefficient for most loans is what we expected-tangible assets should generally support debt better than other types of assets. The positive relationship for PF and FAB could have two explanations. First, it could result from the fact that these types of loans are already concentrated upon funding tangible asset-rich projects, and that the specific industries chosen as "collateralizeable" happen to be relatively riskier than average. Alternatively, it may simply be that riskier projects can be funded using PF or FAB loans than could otherwise be arranged. This is consistent with other loan pricing studies which document that the use of collateral is positively related to loan spreads (Berger and Udell (1990), Booth (1992), and Blackwell and Winters (1997)). We examine this further below for PF loans.

Panel B of Table 5 examines whether the five loan categories in Panel A are priced in segmented or integrated capital markets. A Chow test of structural change is used to test the hypothesis that PF and non-PF loans are functionally equivalent financial instruments priced in a single market. In essence, we are testing whether the loan pricing factors examined in Panel A are significant in both the PF and non-PF regressions and, if so, whether they have the same coefficient values. The Chow test statistics in Panel B are all significantly higher than the critical levels, so we must reject the idea that PF loans are funded in the same market as are other loan classes. PF loans are thus distinctly different financial instruments from other types of syndicated credits, and this means we cannot pool all of our loan observations into one single loan pricing regression. Unfortunately, this also means that we cannot directly test whether PF loans have significantly lower spreads than other types of syndicated credits by including a PF dummy variable in a loan pricing regression of a sample of all loans. Instead, the next section will focus exclusively on PF loans, as we examine the influence of borrower nationality, covenant usage, loan fees, credit risk ratings, and (project) leverage on PF loan pricing.

\section{Determinants of project finance loan pricing}

The Loanware database provides varying amounts of information about project finance credits, depending upon factors such as loan size, nationality of borrower, and especially the date the loan is 
signed. Larger and more recent loans typically have complete information on all of the variables used thus far in our pricing regressions, plus information on covenant usage, fee levels, and borrower (vehicle company) credit rating, whereas smaller and older loans tend to have much less detailed data. Virtually all PF loans booked since 1994 also provide total project size (in US\$ millions), which allows computation of a leverage ratio - at least a measure of the total value of all the PF loan tranches divided by project size. Rather than restrict ourselves to analyzing a single sample with all of this information available (which would yield a sample size of less than 100 loans), we study four different PF loan samples, grouped based on the availability of key data items. These samples are described in Table 6.

\section{$* * * *$ Insert Table 6 about here $* * * *$}

\subsection{Determinants of spreads for the high-information project finance loan sample}

Columns 1 through 6 of Table 6 present expanded loan pricing results for the full-information sample of 1803 PF loans, using the same variables as in Table 5 plus a dummy variable proxying for covenant usage and another dummy variable indicating whether the borrower is located in the United States. The first column employs all of the loan-specific and country risk variables employed before, plus covenant usage and the US borrower dummy variable. Columns 2 through 4 use, respectively, the country risk rank, currency risk, and US dummy variables by themselves, while the next two columns incorporate first risk rank together with currency risk (excluding the US dummy variable) and then currency risk and the US dummy together (excluding rank). This empirical design is necessitated by the fact that the country risk rank, currency risk, and US dummy variables are highly correlated with each other (the pairwise correlation coefficients have absolute values of between 0.65 and 0.82 ).

No matter how the risk measures are expressed, all of the other variables in the high-information PF sample regressions yield consistent results. The intercept falls between 106.6 and 142.9 in all six regressions, and the size and maturity variables are always insignificantly negative. Furthermore, the presence of a third-party guarantee always significantly reduces loan spreads (by between 35.3 and 49.2 basis points), while lending to a borrower in a collateralizeable asset-rich industry always increases 
spreads (by between 14.3 and 21.2 basis points). Whenever employed, the country risk rank variable is also significantly positive, indicating that lending to a borrower with a rank of 30 versus one with a rank of 20 will increase loan spreads by between 11.7 and 15.2 basis points. All of these results are reassuringly similar to those documented earlier in Table 5, so it is clear that simply adding the covenant usage variable to all six regressions does not fundamentally alter the loan pricing results. Insertion of at least one covenant in a credit, however, does significantly increase PF loan spreads (by between 51.1 and 73.5 basis points). The most logical interpretation of this result is that covenants are added to PF loans, as opposed to the detailed covenants included in the supporting project financing credit packages, only for the most risky credits. Since covenants are observed in only 3 percent of PF loans, their use has a magnified impact on spreads.

Not surprisingly, given the high correlation between the three country and currency risk variables, interpreting the separate effects of currency risk and the US dummy variable is rather problematic. We have seen that country risk rank is consistently and significantly positive-with a stable coefficient value - whenever employed. However, currency risk is significantly positive in two regressions and significantly negative in two others, while the US dummy variable is only significant (positive) in one of three regressions. Our conclusion regarding the impact of these variables must therefore be tempered. Nonetheless, a comparison of columns 1 and 5 and columns 3 and 6 indicates that the presence of multicollinearity between country risk rank and currency risk seems to be causing a switch in the currency risk coefficient between the two sets of regressions. This suggests that the currency risk dummy is best interpreted when it is reported in regressions excluding country risk rank and US borrower dummy. In these regression, as reported in columns 3, 8, 10, and 12, currency risk - when priced - has a positive impact on spreads. Furthermore, column 1's regression suggests that US borrowers must pay a 26.8 basis point premium over what borrowers from other countries are charged for otherwise similar project finance loans. 


\section{2. $\quad$ The impact of fees on loan pricing}

Columns 7 and 8 of Table 6 present the results of our loan pricing regressions for a sub-sample of 661 loans with complete fee information. These two regressions examine whether loan spreads and fees are complements or substitutes. In both cases, the coefficients on the (maximum) participation fee and initial commitment fee variables are significantly positive, suggesting that fees and spreads are complements. On average, each additional basis point increase in the maximum participation fee increases the loan spread by $0.53 \mathrm{bp}$, while each additional basis point of initial commitment fee increases the spread by $1.22 \mathrm{bp}$. The most logical interpretation of these findings is that banks are enticed to participate in riskier loans by being offered both higher fees and higher spreads. Not surprisingly, including fees in the regression also significantly reduces the regression intercept, though it remains significantly positive in both regressions. These regressions also have by far the highest explanatory power (adjusted $\mathrm{R}^{2}$ values of 0.40 ) of any of the estimations presented in Table 6 .

With the exception of loan size, all of the other variables in the fee sample regressions have the same sign as in the full-information loan regressions (columns 1-6 of Table 6), though maturity is now significantly negatively related to spread (as it was in Table 5). The coefficient on loan size, however, is significantly positively related to spread, though the coefficients on this variable in columns 7 and 8 indicate that increasing loan size by $\$ 100$ million will increase spreads by an average of only 0.6 basis point.

\subsection{The impact of credit risk on loan spreads}

As mentioned earlier, it is extremely difficult to generate standard leverage, liquidity, and solvency measures for project finance loans. This is both because the Loanware database does not provide a machine-readable borrower code that would allow matching of loan data with company-specific accounting information from other databases and because the stand-alone structure of a project finance vehicle company renders its indebtedness measures non-comparable to those of an operating company. We can, however, generate internally consistent solvency and leverage ratios for two sub-samples of 
project finance loans.

First, columns 9 and 10 of Table 6 present loan pricing regression results for a sample of $193 \mathrm{PF}$ loans which have a credit rating for long-term or short-term debt (or both) from either Moodys or Standard and Poors. These provide an indirect measure of a vehicle company's perceived credit risk. Loanware includes four fields that can be used to measure a borrower's credit rating. These are the Moody's and S\&P ratings for the (overall) vehicle company, plus the separate Moody’s and S\&P ratings for the company's long-term debt. In order to maintain as large a sample as possible, we include all loans that contain at least one rating from any of these four possible rating fields. For loans with more than one rating, the average of all ratings is used. In order to convert the rating Aaa1, Aaa2, Aaa3, Aa1, Aa2, etc into a number, the ratings are ranked and a better rating receives a lower number. Thus, the higher the number, the riskier the loan. For example: Aaa1=0.75, Aaa2 $=1.00$, Aaa3 $=1.25$, etc for Moody's rating. For S\&P's rating, $\mathrm{AAA}+=0.75, \mathrm{AAA}=1.00, \mathrm{AAA}-=1.25$, etc. This coding of the variable borrower rating implies that it will have a positive coefficient, since the higher the rating (the higher the default risk/credit risk of the borrower) the higher the number coded for the borrower rating variable and the higher the spread.

The loan pricing regressions for the ratings sub-sample, presented in columns 9 and 10 of Table 6, show exactly the results expected. A one unit increase in credit risk rating (corresponding to a change from, say, AAA to BBB) is associated with a significant 30.1 to 34.1 basis point increase in a loan's spread. Note also that inclusion of a direct measure of credit risk has a dramatic impact on the regression intercept, causing it to become significantly negative in both regressions (with an average value of -58 bp). The coefficients on loan size and loan term are both insignificant, while covenant usage, lending to a collateralizeable asset-rich borrower, and country risk rank all remain significantly positively related to spread. As always, the presence of a third-party guarantee significantly reduces a loan's price, but both the US dummy variable and the currency risk measure are insignificant. Each of these regressions explains a non-trivial fraction of the total variation in observed loan spreads, yielding adjusted $\mathrm{R}^{2}$ values 
of 0.31 and 0.34 , respectively.

The final two columns of Table 6 present the results of loan pricing estimations of a sample of 192 PF loans booked after 1994. From 1995 onwards, Loanware consistently provides the total size of projects (in \$US millions) funded by PF lending, as well as the total value of all loan tranches. Dividing the total tranche value by the total project value yields a leverage ratio that can be compared across post1994 PF loans. The average leverage ratio thus estimated, 0.67, verifies the commonly-held view that project financing involves a very high level of debt. ${ }^{8}$ As expected, project leverage is highly positively correlated with loan spread. The coefficients for the leverage variable in the regressions presented in columns 11 and 12 average a significant 63.6, implying that increasing a project's leverage from, say, 0.60 to 0.70 would cause loan spreads to increase by about 6.4 basis points.

Incorporating a direct leverage measure into the loan pricing regressions once again causes the two intercepts to have significant positive values - though the difference between the two intercepts, almost 42 basis points, is uncomfortably large ( 45.7 bp versus $87.6 \mathrm{bp})$. As has frequently been the case, loan size and term are insignificantly related to spread, while the coefficient on country risk rank remains significant and positive and that on guarantee is still significantly negative. For the first time, both the collateralizeable asset and covenant usage variables' coefficients are insignificant, as is currency risk in the more extensive model (when it is included along with rank and the US dummy). Also in this model, the US dummy variable is significantly positive, implying that an American project would be charged a rate 51.9 basis point higher than an otherwise similar project located elsewhere.

\section{Estimating an organizational choice model of project finance lending}

We conclude our empirical analysis of project finance lending by examining whether it is possible to predict when project finance lending will be used to fund specific projects. In order to focus

8 As it happens, however, this is actually an under-estimation of total leverage, since it does not include bonds issued along with syndicated loans in many projects. Using a sample of 137 loans with complete information on the total equity contributions for individual project financings, we compute a "total" leverage ratio of 0.71 . 
on the variables that we have, and also to finesse the influence of industry and investment opportunity set on the organizational structure choice, we examine only PF and non-PF loans made to borrowers in industries with at least 100 project finance loans. We thus examine whether it is possible to predict if a particular loan made to a borrower in, say, the oil and gas industry will be structured as a PF loan rather than as a straight syndicated credit, based only on country risk factors and specific characteristics of the loan itself (maturity, size, presence of a guarantee, etc.). We analyze the choice between project finance and non-project finance lending with both logit and probit regression techniques, using a dummy variable coded as 1 if the loan is a project finance loan and zero otherwise. The model we estimate is presented very generally in equation 2 below, along with the empirical variables employed:

Probability $[Y=1]=F$ (size, maturity, country risk, currency risk, guarantee)

All variables are the same as defined in equation 1, except that we use both country risk measures_-rank and score - in separate model estimations for both the logit and probit regressions. Therefore, country risk is measured by rank in the first regression, but is measured by score in the second regression. Since loan spread is not a variable in this model, the peculiar way that country risk score expresses risk (a higher score means lower risk) will not cause difficulties in interpreting the estimation results. The coefficient on the risk variable is simply expected to have a negative value for score and a positive value when rank is used.

The probit and logit regressions differ in the assumption each makes regarding the underlying distribution. Whereas a logit regression assumes a logistic distribution, a probit assumes a normal distribution. As Greene (1990) states, the choice between probit and logit is difficult to justify theoretically and both approaches generally lead to similar results. Thus, both models are presented in table 7.

The sample used to estimate our organizational choice model includes all loans in the Loanware 
database with complete information regarding loan size in US\$ millions, loan maturity, loan currency, borrower nationality, and date of signing. An additional screen requires that the borrower be from an industry that records at least 100 project finance loans during the 1980-1999 study period (see Table 1 for a listing). From these initial screenings, we retain those loans extended to borrowers based in a country for which either a country risk rank or score is reported in Euromoney in the year the loan is signed. These sample selection criteria result in a sample of 22,911 loans with country risk rank information and 21,928 loans with country risk score information. The difference in sample size is due to the fact that, as mentioned previously, Euromoney reported country risk scores for only a few countries prior to 1983 . The PF and non-PF samples created by these screens are qualitatively similar to the samples used in the univariate comparisons and in the loan pricing regressions, though we do not present the sample characteristics in the interest of space. A tabulation of these characteristics is available upon request.

\section{$* * * *$ Insert Table 7 about here $* * * *$}

Our estimation procedure is as follows. First, each sample (one using risk rank, the other using risk score) is sorted randomly. The first 20,000 observations from each sample are then used in the probit and logit regressions, respectively. The results are reported in Panel A of Table 7. In a second step, an optimal cut-off probability is calculated following the approach developed by Palepu (1986). This cut-off probability is used to test the out-of-sample predictive power of the model. For the hold-out samples of 2,911 (country risk rank) and 1,928 (country risk score) loans, we then predict that a particular credit will be structured as a project finance loan if its estimated probability--based on the coefficients in Panel A-lies above the cut-off probability. Conversely, a loan is predicted to be non-project finance if its estimated probability lies below the cut-off probability. These out-of-sample predictions are recorded in Panel B of Table 7.

In addition to the estimated coefficients, Table 7's Panel A also reports the likelihood ratio index for each regression. This index can be interpreted as a pseudo- $\mathrm{R}^{2}$ for linear regressions and thus provides information about the explanatory power of the model being estimated. The regression results in Panel A 
reveal that all variables except the project's size have an influence on the organizational choice. Project finance is chosen for longer-term projects, in riskier countries, which face currency risk and are guaranteed. These results are the same regardless of the underlying distribution assumed (logit versus probit). Also, the two alternative measures of country risk point in the same direction, though the coefficients have opposite signs. The positive coefficient on the country risk rank indicates that project finance is chosen for higher ranking, thus riskier countries. The country risk score coefficient leads to the same conclusion: Project finance is chosen for projects in countries with lower scores, thus higher risk.

The explanatory power of the model can be evaluated by either looking at the likelihood ratio index, which is 21 or 22 percent for all 4 regressions, or by looking at the predictive power of the models as represented in Panel B of Table 7. Here, the probit model clearly provides superior results regarding the project finance sub-samples, since 73 percent of all project finance loans and about 80 percent of all non-project finance loans are correctly predicted using probit regression. Logit provides superior predictive accuracy for non-PF loans, averaging about 90 percent for the two samples, but does so at the cost of correctly predicting the project finance loan choice only 59 percent of the time. Using either probit or logit regression, however, it is worth noting that this simple model correctly predicts the classification of a given loan as either PF or non-PF in almost four out of every five cases.

\section{Summary and conclusions}

This study compares the financial characteristics of a large sample of limited recourse project finance loans to a comparison sample of all non-project finance loans, as well as to various sub-samples of non-PF credits classified by loan purpose. Collectively, these samples represent almost the population of large syndicated bank loans booked on international capital markets since 1980-over 90,000 loans in total, with an aggregate value in excess of $\$ 13$ trillion. We find that project finance (PF) loans differ significantly from non-project finance credits in that PF loans have a longer average maturity, are more likely to have third-party guarantees, and are far more likely to be extended to non-US borrowers and to 
borrowers in riskier countries. PF credits also involve more participating banks, have fewer loan covenants, are more likely to use fixed-rate rather than floating-rate loan pricing, and are more likely to be extended to borrowers in tangible-asset-rich industries such as oil and gas, real estate, and electric utilities.

Despite being non-recourse finance, floating-rate PF loans have lower credit spreads (over LIBOR) than do most comparable non-PF loans. This surprising result clearly indicates that the project financing structure solves important agency costs that are inherent in the creditor/borrower relationship, and that PF is a very effective method of providing monitoring for large projects with relatively transparent cash flows. Also contrary to expectations, we find that PF loans are not larger than non-PF loans, but are in fact significantly smaller than corporate control or capital structure loans (two of the four non-PF loan samples examined). Though PF and (most) non-PF loans are all syndicated bank credits, our univariate comparisons suggest that project finance loans differ rather fundamentally from non-PF credits in almost every important aspect.

The loan pricing regression analyses we perform show econometrically that PF and non-PF credits are in fact different financial instruments. Applying the same pricing estimation model to each loan type reveals that PF and non-PF loans are funded in segmented capital markets, with spreads on PF loans being influenced both by different factors and to different degrees by common factors. PF loan spreads are directly related to borrower country risk, the use of covenants in the loan contract, and project leverage. Spreads are also higher when a borrower is in a tangible -asset-rich industry, while the presence of a third-party guarantee significantly reduces PF loan spreads. Though non-PF loan spreads are negatively related to size, and positively related to maturity, these variables do not significantly influence PF loan pricing in most of our regression analyses. Our finding that PF loan fees are significantly positively related to spreads indicates that fees and spreads are complements, rather than supplements. Other aspects of PF loan syndication patterns — such as a significantly greater number of banks participating in these credits, and much higher fee levels - also suggest that PF loans are relatively more 
difficult to arrange than non-PF loans, perhaps due to the dramatically higher average level of country risk for PF loans. While direct comparisons of the leverage ratios of project finance vehicle companies and the operating companies that arrange most syndicated loans are not possible, we do find that projects funded with PF loans are indeed heavily leveraged — with an average loan to project value ratio of 67 percent.

We complete our study by applying an organizational choice model (using probit and logit regressions) to a large sample of loans extended to borrowers in those industries, which frequently use project finance. We thus test if it is possible to predict whether a given loan extended to a borrower in, say, the airline industry will be structured as a PF or ordinary syndicated credit. Applying our model to two hold-out samples of about 2,000 loans each yields a predictive accuracy of almost 80 percent. 


\section{Bibliography}

Allen, Franklin, 1990. The market for information and the origin of financial intermediation. Journal of Financial Intermediation 1, 3-30.

Allen, Franklin and Anthony M. Santomero, 1998. The theory of financial intermediation. Journal of Banking and Finance 21, 1461-1485.

Barclay, Michael J. and Clifford W. Smith, Jr., 1995. The maturity structure of corporate debt. Journal of Financial Economics 50, 609-631.

Barnish, Keith, Steve Miller, and Michael Rushmore, 1997. The new leveraged loan syndication market. Journal of Applied Corporate Finance 1, 79-88.

Berger, Allen N. and Gergory F. Udell, 1990. Collateral, loan quality, and bank risk. Journal of Monetary Economics 25, 21-42.

Berkovitch, Elazar and E. Han Kim, 1990. Financial contracting and leverage induced over- and underinvestment incentives. Journal of Finance 35, 765-794.

Bizer, David S. and Peter M. DeMarzo, 1992. Sequential banking. Journal of Political Economy 100, 4161.

Black, Fischer and J. C. Cox, 1976. Valuing corporate securities: Some effects of bond indenture provisions. Journal of Financial Economics 31, 351-367.

Blackwell, David W. and Drew Winters, 1997. Banking relationships and the effect of monitoring on loan pricing. Journal of Financial Research 20, 275-289.

Boehmer, Ekkehart and William L. Megginson, 1990. Determinants of secondary market prices for developing country syndicated loans. Journal of Finance 45, 1517-1540.

Boot, Arnoud W.A. and Anjan Thakor, 1993. Security design. Journal of Finance 48, 1349-1378.

Booth, James R., 1992. Contract costs, bank loans, and the cross monitoring hypothesis. Journal of Financial Economics 31, 25-41.

Booth, James R. and Lena Chua, 1995. Structure and pricing of large bank loans. Federal Reserve Bank of San Francisco Economic Review 3, 52-62.

Boyd, John H. and Bruce D. Smith, 1994. How good are standard debt contracts? Stochastic versus nonstochastic monitoring in a costly state verification environment. Journal of Business 67, 539561 .

Bradley, Michael, Gregg A. Jarrell and E. Han Kim, 1984. On the existence of an optimal capital structure: Theory and evidence. Journal of Finance 39, 857-878.

Brealey, Richard A., Ian A. Cooper, and Michel A. Habib, 1996. Using project finance to fund infrastructure investments. Journal of Applied Corporate Finance 9, 25-38. 
Carey, Mark, Mitch Post, and Steven A. Sharpe, 1998. Does corporate lending by banks and finance companies differ? Evidence on specialization in private debt contracting. Journal of Finance 53, 845-878.

Chemmanur, Thomas J., 1997. Credit market reputation and financing through subsidiaries: A theory of limited-recourse project finance. Unpublished working paper. Columbia University.

Chemmanur, Thomas J. and Paolo Fulghieri, 1994. Reputation, Renegotiation, and the choice between bank loans and publicly traded debt. Review of Financial Studies 7, 475-506.

Chemmanur, Thomas and Kose John, 1996. Optimal incorporation, structure of debt contracts, and limited-recourse project financing. Journal of Financial Intermediation 5, 372-408.

Chen, Andrew H., Sumon C. Mazumdar, and M.W. Hung, 1996. Regulations, lender identity and bank loan pricing. Pacific-Basin Finance Journal 4, 1-14.

Chen, Andrew H., Sumon C. Mazumdar, and Yuxing Yan, 2000. Monitoring and bank loan pricing. Pacifi-Basin Finance Journal 8, 1-24.

Chowdry, Bhagwan, 1991. What is different about international lending? Review of Financial Studies 4, 121-148.

Culp, Christopher L. and Andrea M.P. Neves, 1998. Financial innovations in leveraged commercial loan markets. Journal of Applied Corporate Finance 11, 79-94.

Dailami, Mansoor and Danny Leipziger, 1998. Infrastructure project finance and capital flows: A new perspective. World Development 26(7), 1283-1298.

Diamond, Douglas W., 1989. Financial intermediation and delegated monitoring. Review of Financial Studies 51, 393-414.

Diamond, Douglas W., 1989. Reputation acquisition in debt markets. Journal of Political Economy 97, 828-862.

Diamond, Douglas W., 1991a. Debt maturity structure and liquidity risk. Quarterly Journal of Economics $106,711-737$.

Diamond, Douglas W., 1991b. Monitoring and reputation: The choice between bank loans and directly placed debt. Journal of Political Economy 99, 689-721.

Diamond, Douglas W., 1993. Seniority and maturity of debt contracts. Journal of Financial Economics 33, 341-368.

Duffee, Gregory R., 1998. The relation between Treasury yields and corporate bond yields. Journal of Finance 53, 2225-2241.

Eaton, Jonathan, Mark Gersovitz, and Joseph Stiglitz, 1986. The pure theory of country risk. European Economic Review 30, 481-513. 
Edwards, Sebastian, 1984. LDC foreign borrowing and default risk: An empirical investigation, 1976-80. American Economic Review 74, 726-734.

Edwards, Sebastian, 1986. The pricing of bonds and bank loans in international borrowing. European Economic Review 30, 565-589.

Eichengreen, Barry and Ashoka Mody, 2000. Lending booms, reserves and the sustainability of shortterm debt: inferences from the pricing of syndicated loans. Journal of Development Economics $63,5-44$.

El-Gazzar, Samir and Victor Pastena, 1990. Negotiated accounting rules in private financial contracts. Journal of Accounting and Economics 12, 381-396.

Esty, Benjamin C. and Mathew M. Millett, 1998. Petrolera Zuata, Petrozuata C.A. Harvard case number 299012 (Harvard Business School Press).

Greene, William H., 1990. Econometric analysis. MacMillan Publishing Company, New York.

Guedes, Jose and Tim Opler, 1996. The determinants of the maturity of corporate debt issues. Journal of Finance 51, 1809-1833.

Habib, Michel A. and D. Bruce Johnsen, 1999. The financing and redeployment of specific assets. Journal of Finance 54, 693-720.

Harris, Milton and Artur Raviv, 1995. The role of games in security design. Review of Financial Studies 8, 327-367.

Houston, Joel and Christopher James, 1996. Bank Information monopolies and the mix of private and public debt claims. Journal of Finance 51, 1863-1889.

International Finance Corporation, 1999. Project finance in developing countries. IFC Lessons of Experience Series 7, The World Bank Group, Washington D.C.

John, Teresa A. and Kose John, 1991. Optimality of project financing: Theory and empirical implications in finance and accounting. Review of Quantative Finance and Accounting 1, 51-74.

Johnson, Shane A., 1997. The effect of bank debt on optimal capital structure. Financial Management 26 no. $4,47-56$.

Kensinger, John and John D. Martin, 1988. Project finance: Raising money the old-fashioned way. Journal of Applied Corporate Finance 1, 69-81.

Kleimeier, Stefanie and William L. Megginson, 2000. Are project finance loans different from other syndicated credits? Journal of Applied Corporate Finance 13(1), 75-87.

Kleimeier, Stefanie and William L. Megginson, 1998. A comparison of project finance in Asia and the West, in Project Financing in Asia: A Redefining of Premises, L.H.G. Lang, editor. North Holland Publishing, Amsterdam, 57-90. 
Lang, Larry H.G., 1998. Project Financing in Asia: A Redefining of Premises. North Holland Publishing, Amsterdam.

Longstaff, Francis A. and Eduardo S. Schwartz, 1995. A simple approach to valuing risky fixed and floating rate debt. Journal of Finance 50, 789-819.

Maksimovic, Vojislav, 1990. Product market imperfections and loan commitments. Journal of Finance $45,1641-1653$.

Melnik, Arie and Steven Plaut, 1986. Loan commitment contracts, terms of lending, and credit allocation. Journal of Finance 41, 425-435.

Merton, Robert, 1974. On the pricing of corporate debt: The risk structure of interest rates. Journal of Finance 29, 449-465.

Mody, Ashoka and Dilip Patro, 1995. Methods of Loan Guarantee Valuation and Accounting. Working paper, The World Bank, Washington, DC.

Palepu, Krishna G., 1986. Predicting takeover targets. Journal of Accounting and Economics 8, 3-35.

Petersen, Mitchell A., Raghuram G. Rajan, 1994. The Benefits of Lending Relationships: Evidence from Small Business Data. Journal of Finance 49, 3-37.

Rajan, Raghuram G., 1992. Insiders and outsiders: The choice between informed and arm's-length debt. Journal of Finance 47, 1367-1400.

Rajan, Raghuram and Andrew Winton, 1995. Covenants and collateral as incentives to monitor. Journal of Finance 50, 1113-1146.

Rendell, Robert S. and John M. Niehuss, 1983. International project finance, in International Financial Law, 2nd edition, Robert S. Rendell, editor. Euromoney Publications, London, 31-47.

Repullo, Rafael and Javier Suarez, 1998. Monitoring, liquidation, and security design. Review of Financial Studies 11, 163-187.

Scott, Jonathan A. and Terence C. Smith, 1986. The effect of the Bankruptcy Reform Act of 1978 on small business loan pricing. Journal of Financial Economics 16, 119-140.

Shah, Salman and Anjan V. Takor, 1987. Optimal capital structure and project financing. Journal of Economic Theory 42, 209-243.

Smith, Clifford W., Jr., 1980. On the theory of financial contracting - the personal loan market. Journal of Monetary Economics 6, 333-357.

Smith, Clifford W., Jr. and Jerold Warner, 1979. On financial contracting: An analysis of bond covenants. Journal of Financial Economics 7, 111-161.

Smith, Roy C. and Ingo Walter, 1990. Global Financial Services, Harper Business, New York , 191-281.

White, H., 1980. A heteroskedasticity-consistent covariance matrix estimator and a direct test for heteroskedasticity. Econometrica 48, 817-838. 
World Bank, 1994a. Projects with Potential for Cofinancing with Export Credits and Private Financing, The World Bank Group, Washington, DC.

World Bank, 1994b. World Development Report 1994: Infrastructure for Development, Oxford University Press, New York, NY.

World Bank, 1994c. The World Bank's Guarantees: Catalysts for Private Capital Flows, The World Bank Group, Washington, D.C. 
Table 1

Industrial distribution of the sample of project finance loans and the population of all syndicated loans

The first three columns describe characteristics of the sample of loans in the Loanware database with loan purpose code listing as project finance, while the next three columns provide similar information for the full sample of all syndicated loans in this database with a non-empty loan size entry. The first and fourth columns detail the number of each type of loan allocated to borrowers in a particular industry, while the second and fifth columns describe the total value (in US\$ millions) of loans for each industry. The third and last columns present percentages of the total value for each industry.

\begin{tabular}{|c|c|c|c|c|c|c|}
\hline \multirow[b]{2}{*}{ Industrial category of borrower } & \multicolumn{2}{|c|}{ Project Finance Loans } & \multicolumn{4}{|c|}{ All Syndicated Loans } \\
\hline & $\begin{array}{l}\text { Number } \\
\text { of loans }\end{array}$ & $\begin{array}{r}\text { Total value } \\
\text { of loans US\$ } \\
\text { million }\end{array}$ & $\begin{array}{r}\text { Percent } \\
\text { of total } \\
\text { value }\end{array}$ & $\begin{array}{l}\text { Number } \\
\text { of loans }\end{array}$ & $\begin{array}{r}\text { Total value of } \\
\text { loans US\$ } \\
\text { million } \\
\end{array}$ & $\begin{array}{l}\text { Percent of } \\
\text { total value }\end{array}$ \\
\hline Commercial \& Industrial & 3,136 & $\$ 386,862$ & 61.0 & 59,612 & $\$ 8,391,648$ & 63.1 \\
\hline Chemicals, plastic \& rubber & 105 & 8,891 & 1.4 & 2,340 & 321,100 & 2.4 \\
\hline Communications & 241 & 51,126 & 8.1 & 2,237 & 510,242 & 3.8 \\
\hline Construction/heavy engineer & 222 & 15,477 & 2.4 & 1,434 & 75,751 & 0.6 \\
\hline Forest products/packaging & 135 & 15,219 & 2.4 & 1,988 & 299,979 & 2.3 \\
\hline Hotels \& leisure & 298 & 20,628 & 3.3 & 1,992 & 255,184 & 1.9 \\
\hline Mining \& natural resources & 300 & 28,030 & 4.4 & 1,452 & 191,219 & 1.4 \\
\hline Motorway operator & 117 & 14,642 & 2.3 & 342 & 28,636 & 0.2 \\
\hline Oil \& gas & 631 & 119,513 & 18.8 & 6,061 & $1,165,320$ & 8.8 \\
\hline Petrochemicals & 147 & 24,975 & 3.9 & 470 & 89,359 & 0.7 \\
\hline Steel \& aluminum & 215 & 23,488 & 3.7 & 2,098 & 199,275 & 1.5 \\
\hline Utilities & 1,063 & $\$ 140,609$ & 22.2 & 4,644 & $\$ 808,306$ & 6.1 \\
\hline Electricity/energy utility & 1,009 & 136,520 & 21.5 & 3,942 & 714,073 & 5.4 \\
\hline Financial Institutions & 167 & $\$ 21,828$ & 3.4 & 14,051 & $\$ 2,461,411$ & 18.5 \\
\hline Transportation & 143 & $\$ 48,677$ & 7.7 & 5,781 & 711,028 & 5.4 \\
\hline Transport (ex. Airlines, ship) & 112 & 46,788 & 7.4 & 1,870 & 319,180 & 2.4 \\
\hline Government/Agencies & 399 & $\$ 30,602$ & 4.8 & 3,979 & 674,869 & 5.1 \\
\hline Government/authority & 302 & 23,333 & 3.7 & 2,463 & 488,359 & 3.7 \\
\hline Other & 48 & $\$ 5,844$ & 0.9 & 2,716 & 251,211 & 1.9 \\
\hline Total, All Items & 4,956 & $\$ 634,422$ & 100.0 & 90,783 & $\$ 13,298,457$ & 100.0 \\
\hline
\end{tabular}


Table 2

Geographic distribution of project finance loans and the population of all syndicated loans

The first three columns describe characteristics of the sample of loans in the Loanware database with loan purpose code listing as project finance, while the next three columns provide similar information for the full sample of all syndicated loans in this database with a non-empty loan size entry. The first and fourth columns detail the number of each type of loan allocated to borrowers in a particular region (or country), while the second and fifth columns describe the total value (in US\$ millions) of loans for each region. The third and last columns present percentages of the total value for each region.

\begin{tabular}{|c|c|c|c|c|c|c|}
\hline & \multicolumn{2}{|c|}{ Project Finance Loans } & \multicolumn{3}{|c|}{ All Syndicated Loans } & \multirow[b]{2}{*}{$\begin{array}{l}\text { Percent of } \\
\text { total value }\end{array}$} \\
\hline $\begin{array}{l}\text { Geographic Location of } \\
\text { Borrower }\end{array}$ & $\begin{array}{r}\text { Number of } \\
\text { loans }\end{array}$ & $\begin{array}{r}\text { Total value } \\
\text { of loans US\$ } \\
\text { million }\end{array}$ & $\begin{array}{r}\text { Percent } \\
\text { of total } \\
\text { value }\end{array}$ & $\begin{array}{l}\text { Number } \\
\text { of loans }\end{array}$ & $\begin{array}{r}\text { Total value of } \\
\text { loans US\$ } \\
\text { million }\end{array}$ & \\
\hline Supranational & 5 & $\$ 848$ & 0.1 & 313 & $\$ 31,896$ & 0.2 \\
\hline North America & 850 & $\$ 126,155$ & 19.9 & 53,694 & $\$ 8,623,762$ & 64.9 \\
\hline United States & 727 & 106,561 & 16.8 & 51,401 & $8,169,735$ & 61.4 \\
\hline Western Europe & 673 & $\$ 157,223$ & 24.8 & 15,173 & $\$ 2,613,371$ & 19.7 \\
\hline United Kingdom & 306 & 91,751 & 14.5 & 6,109 & $1,230,149$ & 9.3 \\
\hline Eastern Europe & 276 & $\$ 22,046$ & 3.5 & 1,623 & $\$ 156,291$ & 1.2 \\
\hline Middle East & 501 & $\$ 59,286$ & 9.3 & 2,094 & $\$ 217,619$ & 1.6 \\
\hline Turkey & 198 & 14,468 & 2.3 & 813 & 54,808 & 0.4 \\
\hline Africa & 196 & $\$ 12,563$ & 2.0 & 930 & $\$ 60,549$ & 0.5 \\
\hline Indian Sub Continent & 157 & $\$ 11,729$ & 1.9 & 967 & $\$ 58,459$ & 0.4 \\
\hline South East Asia & 1,503 & $\$ 151,004$ & 23.8 & 9,780 & $\$ 688,046$ & 5.2 \\
\hline China & 450 & 29,810 & 4.7 & 1,467 & 89,719 & 0.7 \\
\hline Hong Kong & 134 & 21,689 & 3.4 & 1,553 & 147,766 & 1.1 \\
\hline Indonesia & 260 & 33,210 & 5.2 & 1,392 & 91,912 & 0.7 \\
\hline South Korea & 120 & 8,015 & 1.3 & 1,662 & 85,332 & 0.6 \\
\hline Malaysia & 139 & 17,477 & 2.8 & 841 & 64,965 & 0.5 \\
\hline Thailand & 154 & 17,748 & 2.8 & 1,128 & 64,867 & 0.5 \\
\hline Australia \& Pacific & 246 & $\$ 37,500$ & 5.9 & 2,266 & $\$ 395,197$ & 3.0 \\
\hline Australia & 227 & 36,221 & 5.7 & 1,853 & 349,251 & 2.6 \\
\hline Latin America & 496 & $\$ 52,342$ & 8.3 & 3,303 & $\$ 370,542$ & 2.8 \\
\hline Caribbean & 52 & $\$ 3,646$ & 0.6 & 596 & $\$ 78,816$ & 0.6 \\
\hline Other & 1 & $\$ 79$ & 0.01 & 44 & $\$ 3,920$ & 0.03 \\
\hline Total, All Items & 4,956 & $\$ 634,422$ & 100.0 & 90,783 & $\$ 13,298,457$ & 100.0 \\
\hline
\end{tabular}


Table 3

Financial details of the twenty-five largest project finance deals since 1980

This table provides financing and contracting details regarding the 25 largest total project finance funding packages arranged since 1980 . These are listed by the total value of all loans arranged as part of the package, and details of each loan are presented on each line. The launch date is the date the loan is first formally proposed by the lead bank and the borrower. Loan size gives the value of these credit in US\$ millions (converted into dollars at the contemporaneous exchange rate, when necessary), and the borrower name is the formal name of the vehicle company arranging the credit. Location refers to the country where the project is located, while the identity of the sponsors is provided in the fifth column, whenever provided in the Loanware database. Term refers to the maturity of each loan, while the column labeled Spread describes a loan's price, expressed as basis points over the London Inter-bank Offered Rate (LIBOR). Third-party loan guarantees, if any, are described in the eighth column, while the purpose of the project finance loan package is described in the final column.

\begin{tabular}{|c|c|c|c|c|c|c|c|c|}
\hline $\begin{array}{l}\text { Loan(s) } \\
\text { launch } \\
\text { date }\end{array}$ & $\begin{array}{l}\text { Loan(s) } \\
\text { size, \$US } \\
\text { million }\end{array}$ & $\begin{array}{l}\text { Borrower } \\
\text { Name(s) }\end{array}$ & $\begin{array}{l}\text { Project } \\
\text { location }\end{array}$ & Sponsor Names & $\begin{array}{l}\text { Loan } \\
\text { Term, } \\
\text { years }\end{array}$ & $\begin{array}{l}\text { Spread over } \\
\text { LIBOR, } \\
\text { basis points }\end{array}$ & $\begin{array}{l}\text { Third } \\
\text { party } \\
\text { guarantee }\end{array}$ & Loan purpose : \\
\hline Jun 90 & $\$ 13,204$ & $\begin{array}{l}\text { Eurotunnel plc/SA; } \\
\text { Eurotunnel Ltd; } \\
\text { Eurotunnel Finance SA }\end{array}$ & $\begin{array}{l}\mathrm{UK} / \\
\text { France }\end{array}$ & ---- & $20 \mathrm{yrs}$ & $175.0 \mathrm{bp}$ & None & $\begin{array}{l}\text { Refinancing \& increased } \\
\text { funding for cross- } \\
\text { channel tunnel link }\end{array}$ \\
\hline $\begin{array}{l}\text { Aug } 87 \\
\text { (canc 90) }\end{array}$ & $\begin{array}{l}\$ 6,319 \\
\$ 1,580\end{array}$ & Eurotunnel plc/SA & $\begin{array}{l}\mathrm{UK} / \\
\text { France }\end{array}$ & $\begin{array}{c}--- \\
\end{array}$ & $\begin{array}{l}18 \text { yrs } \\
18 \text { yrs }\end{array}$ & $\begin{array}{l}108.3 \mathrm{bp} \\
141.7 \mathrm{bp}\end{array}$ & None & $\begin{array}{l}\text { Original Eurotunnel } \\
\text { financing }\end{array}$ \\
\hline Mar 93 & $\$ 5,530$ & $\begin{array}{l}\text { Formosa Plastics Corp USA; } \\
\text { Nan Ya Plastics Corp; Formosa } \\
\text { Chemicals \& Fibre; Formosa } \\
\text { Pharmaceuticals }\end{array}$ & Taiwan & ----- & $15 \mathrm{yrs}$ & $75.0 \mathrm{bp}$ & $\begin{array}{ll}--- \\
\end{array}$ & $\begin{array}{l}\text { Construct petro-chemical } \\
\text { project and port complex } \\
\text { in Yunlin province. } \\
\text { Largest Taiwanese } \\
\text { syndicated loan. }\end{array}$ \\
\hline Feb 93 & $\begin{array}{r}\$ 1,995 \\
\$ 1,600 \\
\$ 300 \\
\$ 170 \\
\$ 100\end{array}$ & Qatar Liquified Gas Co. Ltd & Qatar & $\begin{array}{l}\text { Qatar General Petroleum; } \\
\text { Marubeni; Mitsui; Mobil } \\
\text { Corp; TOTAL }\end{array}$ & $\begin{array}{l}12 \text { yrs } \\
---- \\
9 \text { yrs } \\
9 \text { yrs } \\
9 \text { yrs }\end{array}$ & $\begin{array}{l}---- \\
70.0 \mathrm{bp} \\
165.0 \mathrm{bp} \\
---\end{array}$ & $\begin{array}{l}\text { MITI } \\
----- \\
\text { COFACE } \\
----- \\
-----\end{array}$ & $\begin{array}{l}\text { Develop \$6 bn North } \\
\text { Field Ras Laffan LNG } \\
\text { project in Qatar. }\end{array}$ \\
\hline Nov 95 & $\begin{array}{l}\$ 2,598 \\
\$ 1,102\end{array}$ & Railtrack plc & UK & $\begin{array}{ll}--- \\
\end{array}$ & $\begin{array}{l}5.5 \mathrm{yrs} \\
5.5 \mathrm{yrs}\end{array}$ & $\begin{array}{l}27.5 \mathrm{bp} \\
27.5 \mathrm{bp}\end{array}$ & $\begin{array}{c}--- \\
\end{array}$ & $\begin{array}{l}\text { Genl corp purposes \& } \\
\text { construct Thameslink } \\
2000 \text { project }\end{array}$ \\
\hline Jan 98 & $\begin{array}{r}\$ 1,500 \\
\$ 1,195 \\
\$ 500\end{array}$ & NEXTEL Communications & USA & $\begin{array}{ll}---- \\
--1\end{array}$ & $\begin{array}{l}8 \text { yrs } \\
---- \\
8 \text { yrs }\end{array}$ & $\begin{array}{l}200.0 \mathrm{bp} \\
---- \\
200.0 \mathrm{bp}\end{array}$ & $\begin{array}{ll}--- \\
\end{array}$ & $\begin{array}{l}\text { To build firm's } \\
\text { nationwide digital } \\
\text { mobile radio network \& } \\
\text { working capital }\end{array}$ \\
\hline Sep 97 & $\begin{array}{r}\$ 2,168 \\
\$ 642\end{array}$ & $\begin{array}{l}\text { Hutchison Telecommunication; } \\
\text { Orange plc }\end{array}$ & UK & $\begin{array}{ll}---- \\
\end{array}$ & $\begin{array}{l}8 \text { yrs } \\
8 \text { yrs }\end{array}$ & $\begin{array}{l}100.0 \mathrm{bp} \\
100.0 \mathrm{bp}\end{array}$ & $\begin{array}{ll}--- \\
\end{array}$ & $\begin{array}{l}\text { Refinancing of earlier } \\
\text { project financing. }\end{array}$ \\
\hline
\end{tabular}




\begin{tabular}{|c|c|c|c|c|c|c|c|c|}
\hline Jan 97 & $\$ 2,734$ & Bouygues Telecom & France & $\begin{array}{l}\text { Bouygues Decaux } \\
\text { Telecom; Bouygues SA; } \\
\text { Cable \& Wireless; US } \\
\text { West; Faber; BNP-Banexi }\end{array}$ & $10 \mathrm{yrs}$ & $130.0 \mathrm{bp}$ & $\begin{array}{ll}--- \\
\end{array}$ & $\begin{array}{l}\text { Nationwide rollout of } \\
\text { borrower's mobile phone } \\
\text { franchise. }\end{array}$ \\
\hline Jul 96 & $\begin{array}{r}\$ 1,281 \\
\$ 1,036 \\
\$ 403 \\
\end{array}$ & Athens International Airport & Greece & $\begin{array}{l}---- \\
\end{array}$ & $\begin{array}{l}----- \\
----- \\
------ \\
\end{array}$ & $\begin{array}{l}----- \\
\text {------ } \\
\text {------ }\end{array}$ & HERMES & $\begin{array}{l}\text { Construction of new } \\
\text { Athend airport. }\end{array}$ \\
\hline Aug 97 & $\begin{array}{l}\$ 1,363 \\
\$ 1,223\end{array}$ & Alliance Pipeline LP & Canada & $\begin{array}{l}\text { IPL Energy Inc; } \\
\text { Westcoast Energy Inc. }\end{array}$ & $\begin{array}{l}10 \mathrm{yrs} \\
10 \mathrm{yrs}\end{array}$ & $\begin{array}{l}120.0 \mathrm{bp} \\
120.0 \mathrm{bp}\end{array}$ & 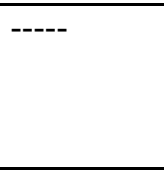 & $\begin{array}{l}\text { Construct pipeline to } \\
\text { carry natural gas from } \\
\text { British Columbia to } \\
\text { Chicago hub. }\end{array}$ \\
\hline Jan 97 & $\$ 2,500$ & Rossijkoje A/O Gazprom & Russia & $\begin{array}{ll}---- \\
\end{array}$ & $8 \mathrm{yrs}$ & $200.0 \mathrm{bp}$ & $\begin{array}{ll}--- \\
\end{array}$ & $\begin{array}{l}\text { Construct pipeline } \\
\text { linking Yamal gasfields } \\
\text { with Europe }\end{array}$ \\
\hline Mar 92 & $\begin{array}{l}\$ 770 \\
\$ 690 \\
\$ 500 \\
\$ 482\end{array}$ & Castle Peak Power Co. Ltd. & $\begin{array}{l}\text { Hong } \\
\text { Kong }\end{array}$ & $\begin{array}{l}\text { China Light \& Power (CLP } \\
\text { Power); Exxon Corp. }\end{array}$ & $\begin{array}{l}20 \mathrm{yrs} \\
13.1 \mathrm{yrs} \\
20 \mathrm{yrs} \\
20 \mathrm{yrs}\end{array}$ & $\begin{array}{l}62.5 \mathrm{bp} \\
53.9 \mathrm{bp} \\
75.0 \mathrm{bp}\end{array}$ & $\begin{array}{l}\text { ECGD } \\
----- \\
\text { COFACE } \\
\text { US EXIM }\end{array}$ & $\begin{array}{l}\text { Construct Black Point } \\
\text { Power Station at Castle } \\
\text { Peak in Hong Kong. }\end{array}$ \\
\hline Nov 93 & $\begin{array}{r}\$ 1,700 \\
\$ 720 \\
\end{array}$ & $\begin{array}{l}\text { Republic of Korea; } \\
\text { Seoul-Pusan High-Speed Rail }\end{array}$ & Korea & ------ & $\begin{array}{l}17.5 \text { yrs } \\
15 \text { yrs }\end{array}$ & $\begin{array}{l}75.0 \mathrm{bp} \\
56.0 \mathrm{bp}\end{array}$ & COFACE & $\begin{array}{l}\text { Purchase TGV trains for } \\
\text { Seoul-Pusan rail link. }\end{array}$ \\
\hline May 97 & $\begin{array}{r}\$ 1,200 \\
\$ 581 \\
\$ 387 \\
\$ 232\end{array}$ & $\begin{array}{l}\text { Loy Yang Power Projects Pty } \\
\text { Ltd }\end{array}$ & Australia & $\begin{array}{l}\text { CMS Generation Co; } \\
\text { NRG Energy Inc }\end{array}$ & $\begin{array}{l}15 \mathrm{yrs} \\
10 \mathrm{yrs} \\
6 \mathrm{yrs}\end{array}$ & $\begin{array}{l}----- \\
----- \\
----- \\
------\end{array}$ & ----- & $\begin{array}{l}\text { Purchase of Loy Yang } \\
\text { Power Station, coal mine } \\
\& \text { other assets from Loy } \\
\text { Yang, wholly- owned by } \\
\text { state of Victoria. }\end{array}$ \\
\hline Jun 90 & $\$ 2,324$ & $\begin{array}{l}\text { Midland Cogeneration } \\
\text { Venture LP }\end{array}$ & USA & $\begin{array}{l}\text { CMS Energy; Dow } \\
\text { Chemical; Fluor; } \\
\text { Panhandle Eastern; Coastal } \\
\text { Corp }\end{array}$ & $25 \mathrm{yrs}$ & ----- & $\begin{array}{ll}--- \\
\end{array}$ & $\begin{array}{l}\text { Construct } 1,370 \mathrm{MW} \\
\text { cogeneration facility in } \\
\text { Midland, MI. }\end{array}$ \\
\hline Jan 97 & $\$ 2,322$ & $\begin{array}{l}\text { Saudi Yanbu Petrochemical; } \\
\text { Yanpet II Project }\end{array}$ & $\begin{array}{l}\text { Saudi } \\
\text { Arabia }\end{array}$ & $\begin{array}{l}\text { Saudi Basic Group; } \\
\text { Mobil Corp }\end{array}$ & $10.5 \mathrm{yrs}$ & $52.5 \mathrm{bp}$ & ------ & $\begin{array}{l}\text { Expansion of three } \\
\text { petrochemical plants at } \\
\text { Yanbu. }\end{array}$ \\
\hline $\operatorname{Jan} 95$ & $\$ 2,300$ & $\begin{array}{l}\text { State Development Bank of } \\
\text { China }\end{array}$ & $\begin{array}{l}\text { China } \\
\text { (PRC) }\end{array}$ & $\begin{array}{ll}---- \\
\end{array}$ & $22 \mathrm{yrs}$ & ----- & $\begin{array}{l}\text { COFACE } \\
\text { (France) }\end{array}$ & $\begin{array}{l}\text { Construct second phase } \\
\text { of Daya Bay Nuclear } \\
\text { Power Station. }\end{array}$ \\
\hline
\end{tabular}




\begin{tabular}{|c|c|c|c|c|c|c|c|c|}
\hline Jun 95 & $\$ 2,000$ & Oman LNG & Oman & $\begin{array}{l}\text { Sultanate of Oman; Shell } \\
\text { Petroleum; TOTAL; } \\
\text { Mitsubishi; Mitsui Corp; } \\
\text { Partex (Oman); Itochu }\end{array}$ & $12.5 \mathrm{yrs}$ & $90.0 \mathrm{bp}$ & $\begin{array}{ll}---- \\
\end{array}$ & $\begin{array}{l}\text { Construct downstream } \\
\text { element of } \$ 6 \text { bn Oman } \\
\text { LNG project. }\end{array}$ \\
\hline Jun 97 & $\$ 2,000$ & $\begin{array}{l}\text { Companhia do Metropolitano de } \\
\text { Sao Paulo (METRO); } \\
\text { Line } 4 \text { Project }\end{array}$ & Brazil & ----- & $\begin{array}{ll}--- \\
\end{array}$ & & ---- & $\begin{array}{l}\text { Construct new subway } \\
\text { line in Sao Paulo }\end{array}$ \\
\hline Dec 94 & $\$ 1,940$ & $\begin{array}{l}\text { Broadband Lessor Trust; } \\
\text { Pacific Bell }\end{array}$ & USA & ------ & 4 yrs & & $\begin{array}{l}--- \\
\end{array}$ & $\begin{array}{l}\text { Support commcl paper } \\
\text { program issued to } \\
\text { construct Broadband } \\
\text { network in CA for } \\
\text { Pacific Bell. }\end{array}$ \\
\hline Oct 95 & $\$ 1,920$ & Hutchison Whampao Ltd & $\mathrm{UK}$ & $\begin{array}{ll}---- \\
\end{array}$ & 8 yrs & $150.0 \mathrm{bp}$ & $\begin{array}{l}--- \\
\end{array}$ & $\begin{array}{l}\text { Build-out of Orange } \\
\text { mobile phone franchise } \\
\& \text { refinance existing } \\
\text { debt. }\end{array}$ \\
\hline Aug 93 & $\$ 1,900$ & Telecom Asia & Thailand & $\begin{array}{l}\text { Nynex Corp; Charoen } \\
\text { Pokphand Group }\end{array}$ & $\begin{array}{c}--- \\
\end{array}$ & $\begin{array}{l}----- \\
\end{array}$ & $\begin{array}{l}--- \\
\end{array}$ & $\begin{array}{l}2 \text { million line telephone } \\
\text { expansion in Greater } \\
\text { Bangkok. }\end{array}$ \\
\hline Aug 96 & $\$ 1,959$ & $\begin{array}{l}\text { Mercury Personal } \\
\text { Communications }\end{array}$ & UK & $\begin{array}{l}\text { Cable \& Wireless; } \\
\text { US West }\end{array}$ & 8 yrs & $150.0 \mathrm{bp}$ & $\begin{array}{ll}--- \\
\end{array}$ & $\begin{array}{l}\text { Refinance existing PF } \\
\text { loan for mobile phone } \\
\text { franchise. }\end{array}$ \\
\hline Apr 96 & $\begin{array}{r}\$ 1,374 \\
\$ 458 \\
\end{array}$ & $\begin{array}{l}\text { TeleWest Communications } \\
\text { Group Ltd }\end{array}$ & UK & $\begin{array}{l}----- \\
\end{array}$ & $9.5 \mathrm{yrs}$ & $\begin{array}{l}225.0 \mathrm{bp} \\
225.0 \mathrm{bp}\end{array}$ & $\begin{array}{ll}--- \\
\end{array}$ & $\begin{array}{l}\text { Build-out of borrower's } \\
\text { UK cable-TV franchises. }\end{array}$ \\
\hline Jul 97 & $\begin{array}{r}\$ 1,692 \\
\$ 133\end{array}$ & E-Plus Mobilfunk GmbH & Germany & BellSouth Corp & $\begin{array}{l}9 \mathrm{yrs} \\
9 \mathrm{yrs}\end{array}$ & $125.0 \mathrm{bp}$ & ---- & $\begin{array}{l}\text { Rollout of E-Plus digital } \\
\text { cellular phone network } \\
\text { in Germany. }\end{array}$ \\
\hline
\end{tabular}


Table 4

Characteristics of project finance loans compared to four loan sub-samples and the full sample of all syndicated loans

Panels A and B present financial details for the full sample of all syndicated loans, plus five sub-samples categorized by loan purpose code. Project finance loans are those made to a vehicle company. Corporate control loans are arranged to fund acquisitions, leveraged buyouts, and employee stock ownership plans. General corporate purpose loans either list this as their loan purpose code or else have no purpose listed. Capital structure loans are those arranged for refinancing, recapitalizations, standby commercial paper facilities, share repurchases, and debtor in possession financing. Finally, fixed asset based loans are arranged to acquire property or other mortgage financing, aircraft, or shipping. Panel A details samples of loans requiring only that the loan amount be available, while Panel B's samples also require that the loan be priced as a floating-rate spread above LIBOR, and that loan maturity and currency be available. Note that in Panel B, the number of loans for which fees or country risk is available is less than the number of observations reported in the first row of the panel. For all syndicated loans the sample size is reduced by less than $1 \%$ when requiring that country risk information is present. When commitment fee or participation fee information is required, the sample size of all syndicated loans falls to 11381 and 11727 loans respectively. Panel C presents tests of significance for the difference in values between project finance and other loan types for all loans with country risk rank information. " Indicates that the difference between the value for this loan type and the value for project finance loans is not significant at the 5\% significance level. All other values are statistically significant at the 5\% level or higher.

Panel A: All loans with \$US amount available

\begin{tabular}{lrrrrrr}
\hline & $\begin{array}{r}\text { All } \\
\text { syndicated } \\
\text { loans }\end{array}$ & $\begin{array}{r}\text { Project } \\
\text { finance } \\
\text { loans }\end{array}$ & $\begin{array}{r}\text { Corporate } \\
\text { control } \\
\text { Loans }\end{array}$ & $\begin{array}{r}\text { General } \\
\text { corporate } \\
\text { purpose } \\
\text { loans }\end{array}$ & $\begin{array}{r}\text { Capital } \\
\text { structure } \\
\text { loans }\end{array}$ & $\begin{array}{r}\text { Fixed asset } \\
\text { based loans }\end{array}$ \\
Variable of interest & 90,784 & 4,956 & 10,795 & 39,653 & 25,313 & 4,680 \\
\hline Number of loans & $13,229,278$ & 634,422 & $2,292,431$ & $4,275,803$ & $5,289,793$ & 410,175 \\
Total volume, \$USm & 146 & 128 & 212 & 108 & 209 & 88 \\
Loan size, \$USm: avg & 50 & 52 & 59 & 39 & 65 & 50 \\
$\quad$ Median & 0.003 & 0.011 & 0.067 & 0.003 & 0.012 & 0.050 \\
$\quad$ Minimum & 15,000 & 13,204 & 14,000 & 7,737 & 15,000 & 4,330 \\
$\quad$ Maximum & 181 & 170 & 345 & 124 & 268 & 102 \\
Avg size all tranches, \$USm & 4.8 & 8.6 & 5.1 & 4.5 & 3.9 & 8.1 \\
Average maturity, years & 5.9 & 13.9 & 2.7 & 4.9 & 3.9 & 6.2 \\
Loans with fixed price (\%) & 69.5 & 38.8 & 84.6 & 66.2 & 70.8 & 72.5 \\
Loans priced vs LIBOR (\%) & 55.8 & 13.9 & 68.8 & 50.3 & 74.0 & 20.4 \\
Loans to US borrowers (\%) & & & & & \\
\hline
\end{tabular}




\begin{tabular}{|c|c|c|c|c|c|c|}
\hline Variable of interest & $\begin{array}{r}\text { All } \\
\text { syndicated } \\
\text { loans } \\
\end{array}$ & $\begin{array}{r}\text { Project } \\
\text { finance } \\
\text { loans }\end{array}$ & $\begin{array}{r}\text { Corporate } \\
\text { control } \\
\text { Loans } \\
\end{array}$ & $\begin{array}{r}\text { General } \\
\text { corporate } \\
\text { purpose } \\
\text { loans } \\
\end{array}$ & $\begin{array}{r}\text { Capital } \\
\text { structure } \\
\text { loans } \\
\end{array}$ & $\begin{array}{l}\text { Fixed asset } \\
\text { based loans }\end{array}$ \\
\hline Number of loans & 40,073 & 1,824 & 6,266 & 15,617 & 13,464 & 1,468 \\
\hline Total volume, \$USm & $8,120,791$ & 322,870 & $1,709,683$ & $2,038,268$ & $3,759,693$ & 130,824 \\
\hline Loan size, \$USm: avg & 203 & 177 & 273 & 131 & 279 & 109 \\
\hline Median & 70 & 70 & 85 & 50 & 100 & 60 \\
\hline Average number of tranches & 1.7 & 2.0 & 2.5 & 1.4 & 1.7 & 1.5 \\
\hline Avg spread over LIBOR, bp & 134 & 130 & 195 & 113 & 135 & 86 \\
\hline Average maturity, years & 4.8 & 8.6 & 5.2 & 4.6 & 4.1 & 7.7 \\
\hline Avg no. of syndicate banks & 10.7 & 14.5 & 11.9 & 9.4 & 11.5 & 9.6 \\
\hline \multicolumn{7}{|l|}{ Average fee levels, bp } \\
\hline Initial commitment fee & 30.8 & 36.9 & 39.5 & 28.0 & 30.8 & 20.2 \\
\hline Max participation fee & 36.9 & 56.3 & 56.1 & 30.7 & 31.6 & 37.2 \\
\hline Loans in US dollars (\%) & 86.8 & 77.7 & 84.5 & 85.6 & 90.6 & 78.9 \\
\hline Loans to US borrowers $(\%)$ & 56.9 & 11.6 & 76.8 & 44.3 & 74.3 & 13.4 \\
\hline Loans with curre & 33.1 & 72.9 & 10.5 & 45.3 & 18.2 & 71.0 \\
\hline Loans with covenants $(\%)$ & 30.5 & 3.4 & 41.6 & 21.3 & 42.4 & 7.1 \\
\hline Average country risk score & 90.0 & 74.6 & 95.4 & 87.3 & 94.1 & 82.7 \\
\hline Average country risk rank & 12.8 & 31.8 & 5.2 & 16.3 & 7.4 & 21.3 \\
\hline Loans with guarantees (\%) & 13.3 & 34.1 & 6.8 & 14.3 & 9.9 & 34.5 \\
\hline \multicolumn{7}{|l|}{ Loans to collateralizeable } \\
\hline asset-rich borrowers (\%) & 14.2 & 27.7 & 8.5 & 12.4 & 11.9 & 69.5 \\
\hline \multicolumn{7}{|c|}{$\begin{array}{l}\text { Panel C: Two-sample t-test assuming unequal variances for loan pricing samples for high-information loans with } \\
\text { country risk rank }\end{array}$} \\
\hline Variable of interest & $\begin{array}{c}\text { Project finance } \\
\text { vs corporate cc } \\
\text { loans }\end{array}$ & $\begin{array}{l}\text { ns Project } \\
\text { ol vs cap }\end{array}$ & $\begin{array}{l}\text { Iinance loans } \\
\text { tal structure } \\
\text { loans }\end{array}$ & $\begin{array}{c}\text { Project finance } \\
\text { vs fixed asset- } \\
\text { loans }\end{array}$ & $\begin{array}{r}\text { oans Project } \\
\text { ased vs gen } \\
\text { pur } \\
\end{array}$ & $\begin{array}{l}\text { finance loans } \\
\text { eral corporate } \\
\text { pose loans }\end{array}$ \\
\hline loan size, US\$m & -6.86 & & -8.53 & 5.76 & & 4.57 \\
\hline maturity, years & 32.78 & & 44.26 & 5.20 & & 39.60 \\
\hline spread over LIBOR, bp & -28.49 & & -2.76 & 17.08 & & 7.70 \\
\hline initial commitment fee, bp & -3.87 & & 9.17 & 18.07 & & 13.50 \\
\hline maximum participation fee, $b p$ & $0.28^{\#}$ & & 14.49 & 8.63 & & 16.33 \\
\hline number of tranches & -13.58 & & 7.74 & 10.60 & & 15.53 \\
\hline number of syndicate banks & 6.94 & & 8.54 & 12.01 & & 14.53 \\
\hline US\$ denomination $(0 / 1)$ & -6.27 & & 12.73 & $-0.62^{\#}$ & & -7.64 \\
\hline US market $(0 / 1)$ & -70.29 & & 74.04 & $-1.61^{\#}$ & & -38.44 \\
\hline collateralizeable assets $(0 / 1)$ & 17.10 & & 14.32 & -26.24 & & 14.08 \\
\hline guarantee $(0 / 1)$ & 23.47 & & 21.08 & $-0.15^{\#}$ & & 17.15 \\
\hline covenants $(0 / 1)$ & -50.49 & & 64.50 & -4.51 & & -33.35 \\
\hline currency risk $(0 / 1)$ & 55.81 & & 49.74 & $1.32^{\#}$ & & 24.52 \\
\hline country risk rank & 47.69 & & 43.55 & 14.06 & & 27.25 \\
\hline
\end{tabular}


Table 5

Loan pricing regressions in segmented versus integrated markets

This table presents an ordinary least squares regression analysis of the determinants of loan pricing spreads for the project finance and four other loan type samples. Panel A presents the analysis for each loan type sample, while Panel B performs a Chow test to determine whether the samples can be pooled into a single sample. The t-statistics are based on heteroskedasticity robost errors according to White (1980) and are reported in parentheses. Note that all reported test statistics in panel B are larger than the corresponding critical values.

Panel A: OLS regression results (dependent variable: spread)

\begin{tabular}{|c|c|c|c|c|c|}
\hline Loan type & $\begin{array}{c}\text { Corporate } \\
\text { control }\end{array}$ & $\begin{array}{c}\text { Capital } \\
\text { structure }\end{array}$ & $\begin{array}{c}\text { Fixed asset } \\
\text { based }\end{array}$ & $\begin{array}{c}\text { General } \\
\text { corporate } \\
\text { purpose }\end{array}$ & $\begin{array}{l}\text { Project } \\
\text { finance }\end{array}$ \\
\hline number of observations & 6258 & 13428 & 1449 & 15429 & 1803 \\
\hline Adjusted $\mathrm{R}^{2}$ & 0.16 & 0.17 & 0.14 & 0.17 & 0.17 \\
\hline \multicolumn{6}{|l|}{ Independent variables: } \\
\hline Intercept & $\begin{array}{l}160.28 \\
(36.63)\end{array}$ & $\begin{array}{l}148.32 \\
(77.66)\end{array}$ & $\begin{array}{l}104.07 \\
(20.54)\end{array}$ & $\begin{array}{l}140.13 \\
(85.20)\end{array}$ & $\begin{array}{l}131.37 \\
(20.94)\end{array}$ \\
\hline Loan size (US\$m) & $\begin{array}{c}-0.04 \\
(-9.24)\end{array}$ & $\begin{array}{c}-0.05 \\
(-15.36)\end{array}$ & $\begin{array}{c}-0.02 \\
(-4.07)\end{array}$ & $\begin{array}{c}-0.06 \\
(-12.62)\end{array}$ & $\begin{array}{c}-0.01 \\
(-1.33)\end{array}$ \\
\hline Maturity (years) & $\begin{array}{c}9.11 \\
(12.82)\end{array}$ & $\begin{array}{c}3.12 \\
(8.85)\end{array}$ & $\begin{array}{c}0.11 \\
(0.21)\end{array}$ & $\begin{array}{c}0.68 \\
(2.47)\end{array}$ & $\begin{array}{c}-0.89 \\
(-2.00)\end{array}$ \\
\hline Guarantee $(0 / 1)$ & $\begin{array}{c}-19.54 \\
(-4.16)\end{array}$ & $\begin{array}{l}-3.70 \\
(-1.41)\end{array}$ & $\begin{array}{c}-5.44 \\
(-1.68)\end{array}$ & $\begin{array}{c}-3.98 \\
(-2.22)\end{array}$ & $\begin{array}{c}-42.67 \\
(-11.27)\end{array}$ \\
\hline Currency risk $(0 / 1)$ & $\begin{array}{c}-62.11 \\
(-13.55)\end{array}$ & $\begin{array}{c}-94.54 \\
(-37.36)\end{array}$ & $\begin{array}{c}-57.99 \\
(-11.52)\end{array}$ & $\begin{array}{c}-98.87 \\
(-47.59)\end{array}$ & $\begin{array}{l}-42.16 \\
(-6.95)\end{array}$ \\
\hline Country risk rank & $\begin{array}{c}1.23 \\
(4.63)\end{array}$ & $\begin{array}{c}0.76 \\
(7.23)\end{array}$ & $\begin{array}{c}0.59 \\
(4.09)\end{array}$ & $\begin{array}{c}1.51 \\
(21.77)\end{array}$ & $\begin{array}{c}1.50 \\
(10.87)\end{array}$ \\
\hline Collateralizable assets $(0 / 1)$ & $\begin{array}{c}-17.42 \\
(-4.09) \\
\end{array}$ & $\begin{array}{c}-11.91 \\
(-4.63) \\
\end{array}$ & $\begin{array}{l}20.50 \\
(5.05) \\
\end{array}$ & $\begin{array}{r}-6.59 \\
(-3.33) \\
\end{array}$ & $\begin{array}{l}15.99 \\
(3.75) \\
\end{array}$ \\
\hline \multicolumn{6}{|c|}{ Panel B: Chow test for differences in pricing factor coefficients } \\
\hline & \multicolumn{2}{|c|}{$\mathrm{CC}$} & $\mathrm{CS}$ & FAB & GCP \\
\hline Capital structure (CS) & \multicolumn{2}{|c|}{185.08} & & & \\
\hline Fixed asset based (FAB) & \multicolumn{2}{|c|}{132.39} & 22.40 & & \\
\hline General corporate purpose (GCP) & \multicolumn{2}{|c|}{361.69} & 45.33 & 12.30 & \\
\hline Project finance $(\mathrm{PF})$ & \multicolumn{2}{|c|}{95.54} & 40.35 & 41.71 & 50.06 \\
\hline
\end{tabular}


Regression analyses of the determinants of project finance loan spreads (loan pricing).

This table presents the results of an ordinary least squares regression analysis of the determinants of loan pricing spreads for the full project finance and for various project finance sub-samples created based upon data availability. Columns 1 through 6 analyze the full project finance loan sample, with various combinations of country risk variables added singly and in combination. Columns 7 and 8 examine a sample of project finance loans that also have complete information on the loan fees charged. Columns 9 and 10 examine a sample of loans with credit ratings data, while columns 11 and 12 present regressions of a sample of loans with data on the \$US amount of total project size. This allows a leverage measure to be calculated. T-statistics are based on heteroskedasticity robost errors according to White (1980) and reported in parentheses. $*$ indicates that the reported coefficient is not statistically different from zero at the $5 \%$ level.

\begin{tabular}{|c|c|c|c|c|c|c|c|c|c|c|c|c|}
\hline Explanatory variables & $\begin{array}{l}1] \\
\text { All PF } \\
\text { loans }\end{array}$ & $\begin{array}{l}2] \\
\text { All PF } \\
\text { loans }\end{array}$ & $\begin{array}{l}3] \\
\text { All PF } \\
\text { loans }\end{array}$ & $\begin{array}{l}4] \\
\text { All PF } \\
\text { loans }\end{array}$ & $\begin{array}{c}5] \\
\text { All PF } \\
\text { loans }\end{array}$ & $\begin{array}{c}6] \\
\text { All PF } \\
\text { loans }\end{array}$ & $\begin{array}{c}\quad[7] \\
\text { PF loans } \\
\text { with fees }\end{array}$ & $\begin{array}{c}\quad[8] \\
\text { PF loans } \\
\text { with fees }\end{array}$ & $\begin{array}{c}9] \\
\text { PF loans } \\
\text { with } \\
\text { rating }\end{array}$ & $\begin{array}{c}10] \\
\text { PF loans } \\
\text { with } \\
\text { rating }\end{array}$ & $\begin{array}{c}\text { [11] } \\
\text { PF loans } \\
\text { with } \\
\text { leverage }\end{array}$ & $\begin{array}{c}{[12]} \\
\text { PF loans } \\
\text { with } \\
\text { leverage }\end{array}$ \\
\hline Intercept & $\begin{array}{l}106.63 \\
(14.92)\end{array}$ & $\begin{array}{l}102.75 \\
(17.63)\end{array}$ & $\begin{array}{l}134.75 \\
(20.53)\end{array}$ & $\begin{array}{l}142.86 \\
(28.47)\end{array}$ & $\begin{array}{l}120.82 \\
(18.39)\end{array}$ & $\begin{array}{l}129.40 \\
(18.60)\end{array}$ & $\begin{array}{l}57.34 \\
(6.34)\end{array}$ & $\begin{array}{l}62.49 \\
(7.35)\end{array}$ & $\begin{array}{l}-63.61 \\
(-2.59)\end{array}$ & $\begin{array}{l}-50.34 \\
(-2.03)\end{array}$ & $\begin{array}{l}45.73^{*} \\
(1.67)\end{array}$ & $\begin{array}{l}87.64 \\
(3.59)\end{array}$ \\
\hline Loan size (US\$m) & $\begin{array}{l}-0.006^{*} \\
(-1.21)\end{array}$ & $\begin{array}{l}-0.004 * \\
(-0.94)\end{array}$ & $\begin{array}{l}-0.009^{*} \\
(-1.35)\end{array}$ & $\begin{array}{l}-0.010^{*} \\
(-1.46)\end{array}$ & $\begin{array}{l}-0.07^{*} \\
(-1.32)\end{array}$ & $\begin{array}{l}-0.009^{*} \\
(-1.32)\end{array}$ & $\begin{array}{l}0.006 \\
(3.26)\end{array}$ & $\begin{array}{l}0.006 \\
(3.13)\end{array}$ & $\begin{array}{l}0.013^{*} \\
(1.20)\end{array}$ & $\begin{array}{l}0.004 * \\
(0.36)\end{array}$ & $\begin{array}{l}-0.024^{*} \\
(-1.79)\end{array}$ & $\begin{array}{l}-0.026^{*} \\
(-1.80)\end{array}$ \\
\hline Maturity (years) & $\begin{array}{l}-0.20^{*} \\
(-0.45)\end{array}$ & $\begin{array}{l}-0.15^{*} \\
(-0.35)\end{array}$ & $\begin{array}{c}-0.55^{*} \\
(-1.21)\end{array}$ & $\begin{array}{l}-0.67^{*} \\
(-1.49)\end{array}$ & $\begin{array}{r}-0.45^{*} \\
(-1.00)\end{array}$ & $\begin{array}{l}-0.46^{*} \\
(-1.00)\end{array}$ & $\begin{array}{l}-1.60 \\
(-2.87)\end{array}$ & $\begin{array}{l}-1.70 \\
(-3.09)\end{array}$ & $\begin{array}{l}1.06^{*} \\
(0.80)\end{array}$ & $\begin{array}{l}0.90^{*} \\
(0.70)\end{array}$ & $\begin{array}{c}0.75^{*} \\
(0.62)\end{array}$ & $\begin{array}{l}0.16^{*} \\
(0.13)\end{array}$ \\
\hline $\begin{array}{l}\text { Collateralizeable } \\
\text { assets }(0 / 1)\end{array}$ & $\begin{array}{l}14.33 \\
(3.37)\end{array}$ & $\begin{array}{l}21.22 \\
(5.13)\end{array}$ & $\begin{array}{l}18.55 \\
(4.13)\end{array}$ & $\begin{array}{l}16.69 \\
(3.67)\end{array}$ & $\begin{array}{l}15.66 \\
(3.73)\end{array}$ & $\begin{array}{l}18.07 \\
(3.97)\end{array}$ & $\begin{array}{l}25.84 \\
(4.99)\end{array}$ & $\begin{array}{l}27.42 \\
(5.22)\end{array}$ & $\begin{array}{l}28.18 \\
(1.91)\end{array}$ & $\begin{array}{l}28.14 \\
(1.93)\end{array}$ & $\begin{array}{l}16.26^{*} \\
(1.26)\end{array}$ & $\begin{array}{l}15.09^{*} \\
(0.27)\end{array}$ \\
\hline Guarantee $(0 / 1)$ & $\begin{array}{c}-42.41 \\
(-11.31)\end{array}$ & $\begin{array}{c}-49.24 \\
(-13.43)\end{array}$ & $\begin{array}{l}-38.14 \\
(-9.41)\end{array}$ & $\begin{array}{l}-35.31 \\
(-9.19)\end{array}$ & $\begin{array}{c}-42.92 \\
(-11.44)\end{array}$ & $\begin{array}{l}-37.87 \\
(-9.34)\end{array}$ & $\begin{array}{l}-34.14 \\
(-7.34)\end{array}$ & $\begin{array}{l}-32.25 \\
(-7.05)\end{array}$ & $\begin{array}{l}-34.16 \\
(-3.01)\end{array}$ & $\begin{array}{l}-28.98 \\
(-2.59)\end{array}$ & $\begin{array}{l}-49.70 \\
(-3.44)\end{array}$ & $\begin{array}{l}-48.25 \\
(-3.23)\end{array}$ \\
\hline Covenant usage $(0 / 1)$ & $\begin{array}{l}52.62 \\
(4.52)\end{array}$ & $\begin{array}{l}73.54 \\
(6.73)\end{array}$ & $\begin{array}{l}56.22 \\
(4.50)\end{array}$ & $\begin{array}{l}51.12 \\
(3.94)\end{array}$ & $\begin{array}{l}61.26 \\
(5.51)\end{array}$ & $\begin{array}{l}52.79 \\
(4.05)\end{array}$ & $\begin{array}{l}52.57 \\
(3.00)\end{array}$ & $\begin{array}{l}45.67 \\
(2.45)\end{array}$ & $\begin{array}{l}45.48 \\
(2.13)\end{array}$ & $\begin{array}{l}30.43^{*} \\
(1.57)\end{array}$ & $\begin{array}{c}-11.42^{*} \\
(-0.50)\end{array}$ & $\begin{array}{l}2.74^{*} \\
(0.13)\end{array}$ \\
\hline Country risk rank & $\begin{array}{c}1.57 \\
(11.61)\end{array}$ & $\begin{array}{c}1.17 \\
(11.19)\end{array}$ & & & $\begin{array}{c}1.52 \\
(11.36)\end{array}$ & & $\begin{array}{c}0.52 \\
(2.68)\end{array}$ & & $\begin{array}{c}1.12 \\
(3.23)\end{array}$ & & $\begin{array}{c}1.73 \\
(3.00)\end{array}$ & \\
\hline Currency risk $(0 / 1)$ & $\begin{array}{l}-26.15 \\
(-4.12)\end{array}$ & & $\begin{array}{c}9.80 \\
(1.97)\end{array}$ & & $\begin{array}{l}-36.31 \\
(-6.03)\end{array}$ & $\begin{array}{l}14.36 \\
(2.65)\end{array}$ & $\begin{array}{l}-8.33^{*} \\
(-1.10)\end{array}$ & $\begin{array}{c}0.93 * \\
(0.17)\end{array}$ & $\begin{array}{l}-1.58^{*} \\
(-0.14)\end{array}$ & $\begin{array}{l}7.79 * \\
(0.76)\end{array}$ & $\begin{array}{c}3.23 * \\
(0.16)\end{array}$ & $\begin{array}{l}51.93 \\
(4.12)\end{array}$ \\
\hline US borrower $(0 / 1)$ & $\begin{array}{l}26.77 \\
(3.73)\end{array}$ & & & $\begin{array}{l}-0.04^{*} \\
(-0.01)\end{array}$ & & $\begin{array}{l}10.43^{*} \\
(1.48)\end{array}$ & $\begin{array}{l}15.00^{*} \\
(1.60)\end{array}$ & & $\begin{array}{l}22.22 * \\
(1.21)\end{array}$ & & $\begin{array}{l}45.31 \\
(2.15)\end{array}$ & \\
\hline $\begin{array}{l}\text { maximum } \\
\text { participation fee }(b p) \\
\text { initial commitment } \\
\text { fee (bp) }\end{array}$ & & & & & & & $\begin{array}{c}0.51 \\
(5.42) \\
1.18 \\
(7.11)\end{array}$ & $\begin{array}{c}0.55 \\
(5.77) \\
1.26 \\
(7.99)\end{array}$ & & & & \\
\hline borrower rating & & & & & & & & & $\begin{array}{l}30.11 \\
(5.51)\end{array}$ & $\begin{array}{l}34.09 \\
(6.25)\end{array}$ & & \\
\hline $\begin{array}{l}\text { project's leverage } \\
\text { level }\end{array}$ & & & & & & & & & & & $\begin{array}{l}65.95 \\
(2.07)\end{array}$ & $\begin{array}{l}61.18^{*} \\
(1.84)\end{array}$ \\
\hline $\begin{array}{l}\text { Adjusted } \mathrm{R}^{2} \\
\text { Number of } \\
\text { observations }\end{array}$ & $\begin{array}{l}0.19 \\
1803\end{array}$ & $\begin{array}{l}0.16 \\
1803\end{array}$ & $\begin{array}{l}0.07 \\
1803\end{array}$ & $\begin{array}{l}0.06 \\
1803\end{array}$ & $\begin{array}{c}0.19 \\
1803\end{array}$ & $\begin{array}{l}0.07 \\
1803\end{array}$ & $\begin{array}{l}0.40 \\
661\end{array}$ & $\begin{array}{l}0.40 \\
661\end{array}$ & $\begin{array}{c}0.34 \\
193\end{array}$ & $\begin{array}{l}0.31 \\
193\end{array}$ & $\begin{array}{l}0.18 \\
192\end{array}$ & $\begin{array}{l}0.12 \\
192\end{array}$ \\
\hline
\end{tabular}


Table 7

Organisational Choice between Project Finance and Non-Project Finance Structure

This table presents the results of estimating an organizational choice model on two samples of syndicated loans which contain full information regarding loan size, loan maturity, borrower nationality, loan currency, loan guarantee, and either country risk rank or country risk score. The resulting two samples are randomly sorted and the first 20,000 observations are used for the regression analysis in panel A, whereas the remaining observations are used for the out-of-sample prediction reported in Panel B. The objective is to determine if the actual choice of organizational form - project finance versus ordinary loan format — can be predicted based upon observed characteristics of the loan and the borrower. In Panel A, T-statistics are in parentheses. Panel B reports results of the out-of-sample prediction using optimal cut-off probabilities as promoted by Palepu (1986).

Panel A: Probit and Logit Regression Results

\begin{tabular}{|c|c|c|c|c|}
\hline & $\begin{array}{c}\text { Probit Regression } \\
1 \\
\end{array}$ & $\begin{array}{c}\text { Probit Regression } \\
2 \\
\end{array}$ & $\begin{array}{c}\text { Logit Regression } \\
1 \\
\end{array}$ & $\begin{array}{c}\text { Logit Regression } \\
2 \\
\end{array}$ \\
\hline number of observations & 20000 & 20000 & 20000 & 20000 \\
\hline Likelihood Ratio Index $\left(\mathrm{R}^{2}\right)$ & 0.21 & 0.22 & 0.21 & 0.22 \\
\hline \multicolumn{5}{|l|}{ Independent variables: } \\
\hline \multirow[t]{2}{*}{ Intercept } & -2.40 & -0.43 & -4.34 & -0.88 \\
\hline & $(-78.51)$ & $(-4.96)$ & $(68.49)$ & $(-5.64)$ \\
\hline \multirow[t]{2}{*}{ Loan size (US\$) } & -0.00 & 0.00 & 0.00 & 0.00 \\
\hline & $(-0.21)$ & $(0.28)$ & $(0.22)$ & $(0.53)$ \\
\hline \multirow[t]{2}{*}{ Maturity (years) } & 0.13 & 0.13 & 0.24 & 0.24 \\
\hline & $(41.23)$ & $(41.49)$ & $(40.17)$ & $(40.13)$ \\
\hline \multirow[t]{2}{*}{ country risk ranking } & 0.01 & & 0.02 & \\
\hline & $(22.07)$ & & $(21.71)$ & \\
\hline \multirow[t]{2}{*}{ country risk score } & & -0.02 & & -0.03 \\
\hline & & $(-22.27)$ & & $(-21.82)$ \\
\hline \multirow[t]{2}{*}{ currency risk $(0 / 1)$} & 0.14 & 0.11 & 0.30 & 0.23 \\
\hline & $(4.29)$ & $(3.15)$ & $(4.93)$ & $(3.65)$ \\
\hline \multirow{2}{*}{ guarantee $(0 / 1)$} & 0.14 & 0.12 & 0.24 & 0.20 \\
\hline & $(4.38)$ & $(0.75)$ & $(4.15)$ & $(3.27)$ \\
\hline \multicolumn{5}{|c|}{ Panel B: Out-Of-Sample Predictive Power } \\
\hline & Probit Regression & Probit Regression & Logit Regression & Logit Regression \\
\hline & 1 & 2 & 1 & 2 \\
\hline number of observations & 2911 & 1928 & 2911 & 1928 \\
\hline optimal cut-off probability & 0.1455 & 0.1459 & 0.1126 & 0.1116 \\
\hline \multicolumn{5}{|l|}{ PF sub-sample: } \\
\hline number of true PF loans & 349 & 228 & 349 & 228 \\
\hline number of predicted PF loans & 256 & 166 & 207 & 135 \\
\hline $\begin{array}{l}\% \text { of PF loans correctly } \\
\text { predicted }\end{array}$ & $73.4 \%$ & $72.8 \%$ & $59.3 \%$ & $59.2 \%$ \\
\hline \multicolumn{5}{|l|}{ Non-PF sub-sample: } \\
\hline$\overline{\text { number of true Non-PF loans }}$ & 2561 & 1699 & 2561 & 1699 \\
\hline $\begin{array}{l}\text { number of predicted non-PF } \\
\text { loans }\end{array}$ & 2020 & 1386 & 2293 & 1546 \\
\hline $\begin{array}{l}\% \text { of non-PF loans correctly } \\
\text { predicted }\end{array}$ & $78.9 \%$ & $81.6 \%$ & $89.5 \%$ & $91.0 \%$ \\
\hline
\end{tabular}

